Article

\title{
Energy and Economic Analysis of Date Palm Biomass Feedstock for Biofuel Production in UAE: Pyrolysis, Gasification and Fermentation
}

\author{
Remston Martis ${ }^{1}$, Amani Al-Othman ${ }^{1}\left(\mathbb{D}\right.$, Muhammad Tawalbeh ${ }^{2}\left(\mathbb{D}\right.$ and Malek Alkasrawi ${ }^{3, *(\mathbb{C}}$ \\ 1 Department of Chemical Engineering, American University of Sharjah, Sharjah P.O. Box 26666, UAE; \\ rmartis@aus.edu (R.M.); aalothman@aus.edu (A.A.-O.) \\ 2 Sustainable and Renewable Energy Engineering Department, University of Sharjah, \\ Sharjah P.O. Box 27272, UAE; mtawalbeh@sharjah.ac.ae \\ 3 Department of PS \& Chemical Engineering, University of Wisconsin, Stevens Point, WI 54481, USA \\ * Correspondence: malkasra@uwsp.edu
}

Received: 16 October 2020; Accepted: 6 November 2020; Published: 11 November 2020

\begin{abstract}
This work evaluates date palm waste as a cheap and available biomass feedstock in UAE for the production of biofuels. The thermochemical and biochemical routes including pyrolysis, gasification, and fermentation were investigated. Simulations were done to produce biofuels from biomass via Aspen Plus v.10. The simulation results showed that for a tonne of biomass feed, gasification produced $56 \mathrm{~kg}$ of hydrogen and fermentation yielded $233 \mathrm{~kg}$ of ethanol. Process energy requirements, however, proved to offset the bioethanol product value. For 1 tonne of biomass feed, the net duty for pyrolysis was $37 \mathrm{~kJ}$, for gasification was $725 \mathrm{~kJ}$, and for fermentation was $7481.5 \mathrm{~kJ}$. Furthermore, for 1 tonne of date palm waste feed, pyrolysis generated a returned USD \$768, gasification generated USD 166, but fermentation required an expenditure of USD 763, rendering it unfeasible. The fermentation economic analysis showed that reducing the system's net duty to $6500 \mathrm{~kJ} /$ tonne biomass and converting 30\% hemicellulose along with the cellulose content will result in a breakeven bioethanol fuel price of $1.85 \mathrm{USD} / \mathrm{L}$. This fuel price falls within the acceptable 0.8-2.4 USD/L commercial feasibility range and is competitive with bioethanol produced in other processes. The economic analysis indicated that pyrolysis and gasification are economically more feasible than fermentation. To maximize profits, the wasted hemicellulose and lignin from fermentation are proposed to be used in thermochemical processes for further fuel production.
\end{abstract}

Keywords: energy integration; pyrolysis; gasification; fermentation; biomass; biofuels; process simulation; Aspen Plus

\section{Introduction}

Energy consumption is directly linked to demand from population growth and a need for community advancement. While energy consumption is not a problem, the source of energy to consume has a drastic effect on the ecosystem and its inhabitants. Moreover, one of the most discussed topics of the decade, the Paris Agreement, has enlisted all nations to adhere to and actively work toward the $2{ }^{\circ} \mathrm{C}$ global temperature rise benchmark. Greenhouse gas emissions, particularly $\mathrm{CO}_{2}$, have been identified as the key contributor to global warming [1,2].

At present, fossil fuels continue to play the biggest role in satisfying almost two-thirds of the world's energy needs. However, these reasons are a product of centuries of intense research and development efforts led by several nations and operating companies. Other factors that are usually overlooked when comparing different energy sources are capital investments and job creation. The fossil fuel industry employs many people around the world. However, there is a growing acceptance of the 
evident pitfalls of the fossil fuel sector which has plagued the global economy, particularly in recent years. Due to the volatility in oil prices, even countries rich in oil and gas will struggle to meet world energy demands as a result of competing prices with alternative energy sources, a relentless push for investments into the renewable energy market, and depletion of fossil fuel reserves [3,4].

Biomass, which currently satisfies $12 \%$ of the world's energy needs, is organic material that is obtained from living matter such as plants, trees, algae, organic waste, etc.; this is exclusive of fossil fuels $[5,6]$. While some may see the complexity of biomass as a hurdle, it is this quality that makes it a very versatile fuel. Biomass is usually a waste organic matter that would end up in the landfill one way or another if not collected and utilized [6]. Crop stubble also falls into the category of waste plant matter. It is common practice for farmers to burn the crop stubble after harvesting and before planting the new cycle of crops. For a long time, it has been known that the burning of crops to clear land causes immense pollution, releasing large amounts of aerosols and GHGs, which adversely affect human health and the climate $[7,8]$. Sharma et al. investigated the burning of biomass in Punjab, India and the drop in air quality and found that when fields are burned, a huge amount of aerosol particles are released along with $\mathrm{CO}_{2}, \mathrm{CO}, \mathrm{CH}_{4}$, and other volatile compounds [9]. Another study by Jain et al. found that in India alone, biomass residue burned on farms accounted for nearly 100 metric tons $(15.9 \%)$ of the total 620 metric tons of waste [8].

There are several subtropical lignocellulosic feedstocks such as perennial grasses which have been investigated for direct fuel and biofuel production [10-12]. These feedstocks include but are not limited to corn, corn stover, sugar cane stalk, sugar beet leaves, giant reedgrass, elephantgrass/Napier grass, sweet sorghum, coffee pulp, and Erianthus [10,11]. The lignocellulosic feedstock (either whole crop or its residue waste) is characterized by high field yields (tons/acre), water consumption, energy yield (kJ/acre), production cost, GHG emission, and life cycle analysis [13,14]. Gurram et al. 2015 [15] evaluated coffee pulp for bioethanol production and show that the process yields higher energy with lower GHG emission versus other crops.

Bioethanol production from corn ethanol is predominantly utilized in the US, with a capacity of 57 billion liters annually, and the demand is expected to increase to $42 \%$ in 2020 . Other ways of utilizing lignocellulosic biomass beyond conversion into fuels and chemicals include wastewater treatment as a bioadsorbent agent of heavy metal from wastewater [16,17].

While several of these biomasses have been assessed in various bioenergy processes (fermentation, gasification, and pyrolysis) for more than thirty years, no significant large-scale commercialization exists. The main factor that affects the commercial success is the economic factor, which is based on fuel production cost versus fossil fuel cost.

Crops rich in starch are an ideal source of biofuel production. These came to be known as first-generation feedstocks and include corn, oilseed, and sugar cane [18]. However, since these crops are edible, using them as feedstock for bioenergy production will lead to competition between the food and energy sectors. Second-generation feedstock is the most preferred since it includes waste from the wood industry, residue from forest exploitation, dedicated crops, and agricultural wastes [19-21]. These lignocellulosic wastes are the largest renewable source of bioenergy which, to a large extent, are wasted. Algae are classified as a third-generation feedstock [22,23]. Therefore, the major factors in the selection of the type of biomass depend on the process technology used, the cost of the crop-including collection and logistics—and the significance of the crop as a food source, as observed in Reference [19] and References [24,25]. From this, it is clear why second-generation biomass sources are preferred for biofuel production.

In the Middle East and North Africa (MENA) region, there is a growing interest in bio-energy synthesized from readily available, non-competing crops such as date palm waste [26]. The first cultivations of date palms date back to more than 7000 years ago. The signs of date palm cultivation have been dated back to as early as the Neolithic/Early Bronze Age and it has been considered to be an integral part of the diet of the inhabitants of Southwest Asia and the Mediterranean regions [27,28]. The reason that date palm cultivation has withstood the test of time is that these plants have the 
ability to thrive in very harsh environments, in regions with temperatures as high as $50^{\circ} \mathrm{C}$, and can even withstand short periods of frost $\left(-5^{\circ} \mathrm{C}\right)$ [29]. The arid and semi-arid regions in the MENA region and parts of Asia, particularly Pakistan and India, are very favorable for date palm cultivation. Currently, the world produces 8.5 million tons of dates, and a bulk of the edible fruit, around $89 \%$, originates from the Arabian Peninsula [30]. To add to the versatility of this crop, while the date palm has an average economic life of 50 years, there have been reports of trees being productive for up to 150 years [29]. According to the most recent data by the Food and Agriculture Organization (FAO) of the United Nations, the UAE produced 345,119 tonnes of dates in 2018, which is a $44 \%$ increase from what the country was producing in 2011 [31]. There has also been a lot of support geared toward improving date palm production in the UAE [32]. The UAE has also invested in a Date Palm Tissue Culture Laboratory at UAE University to grow dates effectively and economically in a controlled environment, thereby negating the effects of unpredictable climate, pest infestation, and large-scale cultivation of genetically similar crops [33]. Al-Khyari et al. have proposed several breeding methods and biotechnological tools to enhance crop yield, improve fruit quality, and fortify the crop's resistance to biotic and abiotic stressors [34]. While there have been questions on decreasing groundwater levels, implementing a sustainable irrigation management system, as pointed out by Muaini et al., will encourage crop sustenance [35]. Due to the date fruit's high nutritional value, health benefits, socioeconomic significance, and traditional importance [36-38], the date palm will continue to be a widely cultivated crop in the Middle East, Africa, and Southwest Asia regions. Overall, it can be clearly seen that the efforts toward the production of more dates have drastically increased in the past two decades, led by Egypt, Saudi Arabia, United Arab Emirates (UAE), Iran, and Iraq, generating nearly $60 \%$ of the world's produce [30]. Much of the date fruit that is too soft or of poor quality is usually not sold and is categorized as waste. Hence, the exploitation of such an enormous amount of waste dates is crucial in the UAE region. There are several challenges that hinder the commercialization of biomass conversion processes [39]. The economic challenges are the most important because it is still difficult to resolve them in a short period of time as they require detailed investigation [40]. The cost of biomass conversion into biofuels and chemicals faces several challenges towards commercial implementation. The economic challenges rise from the fact that the conversion process consumes more energy than it produces. Successful scenarios in recent years have used strategies that produce more energy than they consume. Nevertheless, the price of biomass-derived fuel is higher than fuels derived from fossil fuels. From a thermodynamics point of view, energy integration and heat waste minimization would increase the energy output versus the consumed, which would narrow the gap between biomass-based fuel versus fossil-based fuel [21]. The right strategy to accomplish this is to implement a biorefinery design where several fuels are produced from various processes, as proposed in this work. The state of the art of this process is the possibility of minimizing heat loss by integrating the energies of gasification, pyrolysis, and fermentation. The biorefinery approach is a multi-product approach that increases the overall process revenue.

The date palm (Phoenix dactylifera L.) plays a very significant role in supporting life, nutritionally and economically, in the Arab world [41]. There are around 120 million date trees in the world and, apart from the date fruit, each palm tree generates over 20-35 kg of waste every year, which can be harvested to generate biogas, biopolymers, wooden boards, diesel blends, ethanol, butanol, biosurfactants, and so much more, as observed in References [29] and [41]. The potential amount of useable date palm waste from the five leading date palm cultivating nations amounts to 2.16 million $\mathrm{kg}$ of waste annually. To the best of the authors' knowledge, there is no study on the comprehensive energy evaluation at the industrial scale for the utilization of date palm waste in biofuel production, especially in UAE. Therefore, the objective of this work is to evaluate the potential of converting date palm waste, as a biomass feedstock in UAE, to biofuel via pyrolysis, gasification, and fermentation pathways using Aspen Plus v.10. The developed model will offer a basis to study the process improvement through byproduct utilization, heat recovery, and proposed technological advances. 
An economic assessment was also conducted to verify whether the processes are feasible for large-scale production or not.

\section{Methodology and Model Development}

An overview of the common reactions has been presented in the following subsections to garner an understanding of what takes place in each of the processes. Pyrolysis of biomass is the thermochemical process of heating it to high temperatures in the absence of an oxidizing agent to break the large organic molecule chains and produce bio-oil (liquid), bio-char (solid), and pyro-gas (gas). Pyrolysis reactions have been covered and explained in detail in the work by Ranzi et al. [42]. The key parameters include: the temperature rise in the reactor and heating of biomass, release of volatiles at sufficiently high temperatures, the flow of hot vapors towards cooler solids, which causes further pyrolysis, condensation of volatiles over cooler parts in the feedstock/reactor, primary and secondary reactions occurring in parallel, and the extent of thermal decomposition, reforming and dehydration of fuel determined by the operating parameters. Gasification is essentially a step which takes place after pyrolysis, in which reduction is carried out in an oxygen-deficient condition. In the gasification step, the bio-oils and tars undergo further decomposition and reformation to the most stable hydrocarbon forms. In fermentation, cellulose and hemicellulose are broken down into fermented sugars such as glucose and xylose before being converted into marketable ethanol. Since biomass varies in its properties and chemical composition, the following assumptions were made in this context:

- The processes are carried out at a steady-state, reactions occur in thermodynamic equilibrium, and reaction kinetics are not considered.

- Char is $100 \%$ carbon and biomass yield is specified on an ash-free basis.

- Processes are isothermal and the devolatilization, pyrolysis, and gasification steps take place instantaneously.

- For thermochemical processes, it is assumed that $100 \%$ decomposition of biomass into its elemental composition and eventually into final products takes place.

- Phase/component splitters achieve perfect separation.

- Only the most commonly occurring and major compounds are defined in the simulations. Trace components present in bio-oil are not considered.

- Particle size and distribution have not been considered in the simulation. The biomass feedstock is considered to be uniformly ground and possess optimal physical characteristics (size, shape, and distribution).

- In the thermochemical models, the drying block, i.e., the drier and downstream separator (SEP1), is operated adiabatically.

\subsection{Biomass Properties in this Work}

Plant-based biomass is mainly constituted of extractives, cell walls, and ash. The plant cell wall, also termed lignocellulose, is comprised of cellulose, hemicellulose, and lignin. Generally, in lignocellulosic biomass, hemicellulose constitutes $20-40 \mathrm{wt} \%$, cellulose $40-60 \mathrm{wt} \%$, and lignin $10-25 \mathrm{wt} \%$, but these could vary depending on the plant species. In this work, dry date palm waste is considered to be composed of $44.40 \mathrm{wt} \%$ cellulose, $24.30 \mathrm{wt} \%$ hemicellulose, and $31.30 \mathrm{wt} \%$ lignin [43]. These make up the fibrous part of the plant, which is not easily consumable in the diet and renders the material as waste. Rice husk is a good example. The elemental composition also varies due to the presence of several minerals. Different types of plants yield different biomass compositions. According to a recent study by Makkwai et al., variation in date palm waste particle size did not affect the reactor hydrodynamics [44]. However, larger particle sizes yielded higher quantities of bio-oil and non-condensable gas and a lower quantity of char. To a large extent, biomass is organic. However, it also contains traces of inorganic matter, which vary significantly among different feedstocks. Biomass is defined as a non-conventional 
solid in Aspen Plus. The proximate, ultimate, and sulfur analyses presented in Table 1 are for a mixture of date palm leaves, leaf stems, and empty fruit bunches adapted from the work by Makkawi et al. [45].

Table 1. Proximate analysis, ultimate analysis, and sulfur analysis of date palm waste [45].

\begin{tabular}{ccc}
\hline Analysis Type & Component & $\mathbf{w t} \%$ \\
\hline & Moisture & 10.61 \\
Proximate Analysis & Fixed Carbon & 14.63 \\
& Volatile & 64.70 \\
& Matter & 10.06 \\
& Ash & 42.5 \\
& Carbon & 5.78 \\
& Hydrogen & 0.88 \\
& Nitrogen & 0 \\
Ultimate Analysis & Chlorine & 0.19 \\
& Sulfur & 50.65 \\
& Oxygen & 0 \\
& Water & 0 \\
Sulfur & Ash & 0.05 \\
Analysis & Pyritic & 0.1 \\
& Sulfate & 0.04 \\
\hline
\end{tabular}

Furthermore, ultimate analysis was used to determine the elemental composition of the biomass sample. The values in Table 1 were used as inputs in the Aspen Plus simulations. Ash is the leftover content after the biomass sample is burned and is an input that is required to be fed into Aspen Plus (simulation software). However, water is not an input for the ultimate analysis and will be deleted from the ultimate analysis in Table 1 . Since the value was taken as 0 , the results will not be impacted in any way. Values from Table 1 are selected from [45], where the ultimate analysis only specifies $\mathrm{C}, \mathrm{N}, \mathrm{H}, \mathrm{S}, \mathrm{Cl}$, and the final product fractions are specified on an ash-free basis. The values specified in the ultimate analysis are used to predict the composition of the final product. Moreover, since the composition of the ash is not known, it was reasonable to specify the final product as a mixture of the aforementioned elements in which ash is included. In this study, ash will be included in the carbon content.

Since it is quite difficult to find sulfur composition categorized as pyritic, sulfate, and organic, the sum of the three was set to the total sulfur composition in the ultimate analysis.

\subsection{Pyrolysis Model}

Wet biomass is mixed with a stream of air at $50{ }^{\circ} \mathrm{C}$ in a DRIER. The WATER calculator block computes the fraction of moisture that evolves as a result, which is then separated in SEP-1. Figure 1 shows the Aspen Plus simulation for pyrolysis. In some cases, not all the evolved moisture leaves in the EXHAUST. Any water present in liquid form is split from pure dry biomass in a phase separator-PSPLIT. This step is purely to simplify the DECOMP and devolatilization steps that follow. In this model, dry biomass flows into DEVOL, where it begins to thermally decompose into its elemental compositions, which is specified in the ultimate analysis. However, in reality, the biomass thermally degrades to the proximate analysis components, i.e., water, volatiles such as carbon monoxide (CO), carbon dioxide $\left(\mathrm{CO}_{2}\right)$, hydrogen $\left(\mathrm{H}_{2}\right)$, methane $\left(\mathrm{CH}_{4}\right)$, etc., and tars, solid carbon, and ash. Since the yields of the volatile compounds are not known and reaction kinetics are not employed, the best way to predict the yields is by decomposing the biomass to its elemental composition and then carrying out reactions using the Gibbs free energy principle. The decomposed product leaving the DEVOL reactor is then recombined with liquid water. As mentioned earlier, the trace water that evolves during the drying stage and remains with the solid biomass needs to be separated prior to the devolatilization step in order to simplify the DEVOL calculator FORTRAN code and avoid a complicated computational step. The water present in the biomass is in a very small quantity, which makes this method a reasonable assumption to make. Since the liquid water is also one of the inputs in the biomass ultimate analysis, bypassing the DEVOL reactor does not have an impact on devolatilization calculations. Next, the mixed 
stream passes into the pyrolysis phase. PYROL is an RGIBBS reactor that runs at $500{ }^{\circ} \mathrm{C}$. According to El May et al., the $200^{\circ} \mathrm{C}$ devolatilization temperature falls within the devolatilization range for the selected date palm waste mixture in this study [46]. The same study also indicates that at $500{ }^{\circ} \mathrm{C}$, much of the weight loss due to moisture evolution, cellulose decomposition, and hemicellulose decomposition would have already taken place. After the pyrolysis stage is complete, the char is separated from the volatiles using a phase splitter-SSPLIT. The hot volatile gas is passed through HEATX-1 to heat up the incoming dry air stream.

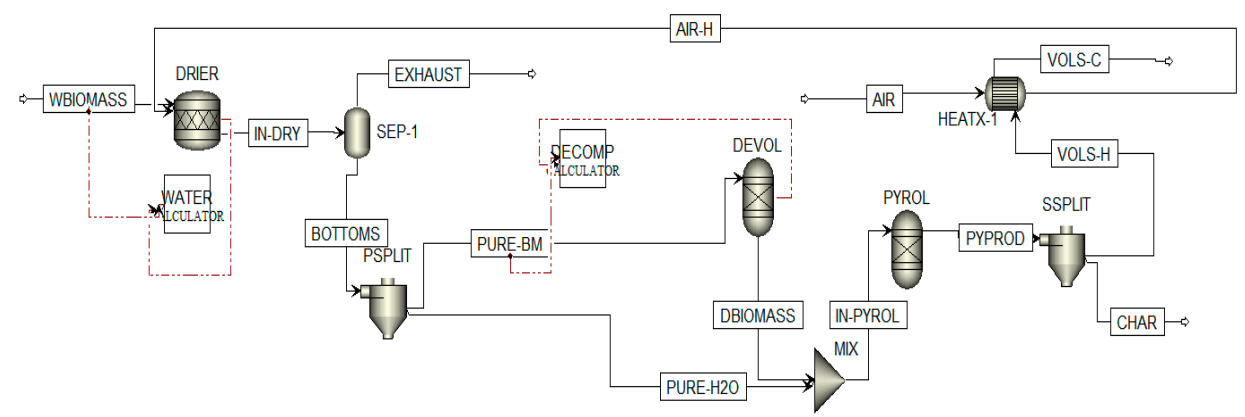

Figure 1. Aspen Plus simulation for pyrolysis.

\subsection{Gasification Model}

The gasification model is developed as an extension from the pyrolysis model and shown in Figure 2. The only difference between the two models is an air feed for the gasification reactor (GASIF) and HEATX-2 to heat the air feed to $850^{\circ} \mathrm{C}$. Just as in the pyrolysis model, wet biomass is air-dried in DRIER and the evolved moisture is separated in SEP1. Pure dry biomass undergoes devolatilization followed by gasification in GASIF. The optimal air to fuel ratio is 1:3 on a mass basis. The required quantity of air, i.e., $30 \%$ air (on a mass basis) per feed of pure biomass entering the gasifier, is calculated by the AIR-FUEL calculator block. GASIF is an RGibbs reactor which is operated at $900{ }^{\circ} \mathrm{C}$. The use of the RGibbs reactor ensures $100 \%$ conversion of biomass to final products. This is exactly what is expected to happen in a real gasification process as gasification at high temperatures ensures thermal cracking of the organic compounds to near completion. As such, no reaction kinetics are modeled. In the RGibbs reactor, the most commonly occurring gasification products, i.e., $\mathrm{CO}, \mathrm{CO}_{2}, \mathrm{H}_{2}$, non-condensable gases, benzene, toluene, heavy hydrocarbons, alcohols, aldehydes, etc., are selected and the components are formed based on their Gibbs free energy. To develop models that involve reaction kinetics in future work, a list of homogeneous and heterogeneous reactions that occur during gasification of biomass is presented in the work by Makkawi et al. [47].

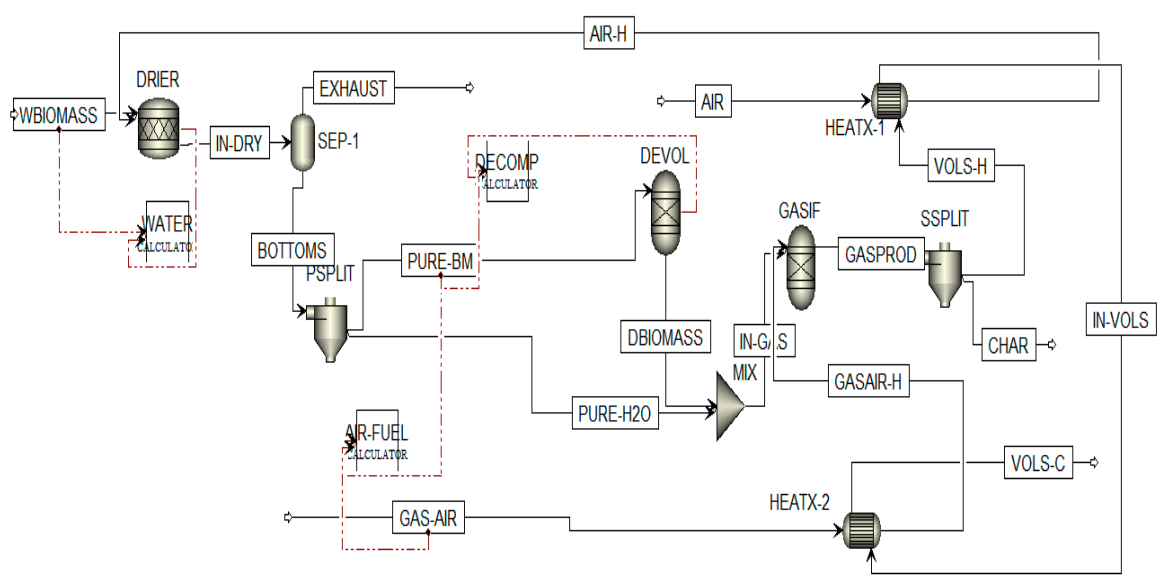

Figure 2. Aspen Plus simulation for gasification. 


\subsection{Fermentation Model}

Biomass can be pretreated physically, chemically, physicochemically, or biologically. Figure 3 shows a simplified block diagram for the fermentation process. Using supercritical $\mathrm{CO}_{2}$, a relatively new technology, in pretreating cotton stalks increased the methane and biogas yield by $29 \%$ and $20 \%$, respectively [48]. In this study, the steam explosion pretreatment of biomass was adopted. In a recent study on wheat, rice, and maize straws, the steam explosion caused drastic changes to the overall composition of the polymeric chains and, depending on the type of crop, the cellulose, hemicellulose, and lignin contents were affected [49]. Steam explosion is generally carried out using saturated steam at $160-290^{\circ} \mathrm{C}$ and $0.69-4.85 \mathrm{MPa}$. These operating conditions are held for a few seconds or minutes and then are decompressed to atmospheric pressure. In a study by Steinbach et al., the steam explosion on rice straw was shown to increase biogas yield. The experiment was carried out with steam at $206^{\circ} \mathrm{C}$ and at 18.5 bar for $30 \mathrm{~min}$ and resulted in increasing the porosity of biomass and yielded more water-soluble components [50]. Another study on producing biofuels from Miscanthus lutarioriparius (a type of indigenous African grass) indicated that the steam explosion increased biomass surface area, which in turn enhanced the final fuel yield [51].

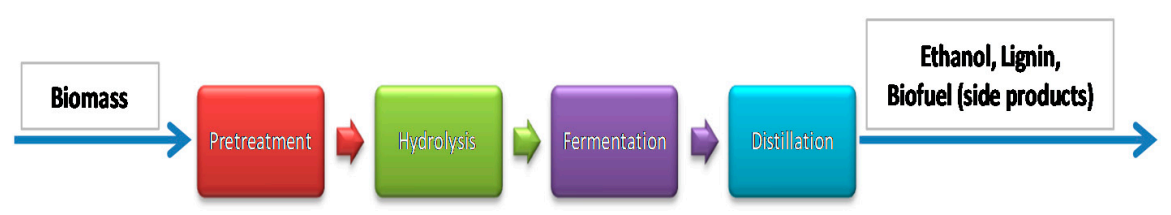

Figure 3. A simplified block flow diagram of the fermentation process.

Steam explosion treatment has its downsides too. Studies have shown that sudden depressurization not only damages the hemicellulose but also defibrillates the cellulose polymer chains and causes fractionation of sugars and lignin, leading to the production of compounds that inhibit the enzymatic hydrolysis [52]. In most cases, the steam explosion dissolves hemicellulose and causes a slight degradation of lignin and cellulose. However, it still is an excellent method to improve the enzymatic accessibility for the steps that follow in the fermentation process. Since biofuels are mainly targeted towards helping to develop rural areas, using high-pressure steam seems like a much safer alternative, in terms of handling and potential human/environmental risk, than using strong acids.

Figure 4 shows the simulation for the fermentation process. In this model, perfect separation of biomass into its constituent components, i.e., cellulose, hemicellulose, and lignin, is assumed prior to the feed. In addition to this, for the sake of simplicity, reactions involving hemicellulose and lignin are not considered. Hence, stream S1 contains pure solid cellulose and water only. The cellulose content in $\mathrm{S} 1$ is specified as $44.4 \%$ of a $2000 \mathrm{~kg} / \mathrm{h}$ biomass feed and the leftover $1112 \mathrm{~kg} / \mathrm{h}$ mixture of hemicellulose and lignin is not modeled in this process. First, $888 \mathrm{~kg}$ of cellulose and $5000 \mathrm{~kg}$ of water are fed into the system under atmospheric conditions of $20^{\circ} \mathrm{C}$ and 1.01325 bar. PUMP1 is used to bring the feed supply pressure up to 8.62 bar and HEATEX-1 increases the stream temperature to $160^{\circ} \mathrm{C}$. These are the conditions required for steam explosion pretreatment. The PRETREAT reactor is defined as an RStoic reactor in which cellulose reacts with water at the same condition of the incoming feed stream to form glucose in stoichiometric amounts. The fractional conversion is set to 0.42 of cellulose. After leaving the PRETREAT reaction, the pressure is dropped to 1.01 bar across PUMP-2, and HEATEX-2 is set to regulate the temperature at $50^{\circ} \mathrm{C}$. Ideally, pressure in the stream can be eliminated via a control valve or energy can be recovered via a turbine. However, this was not considered during model development. 


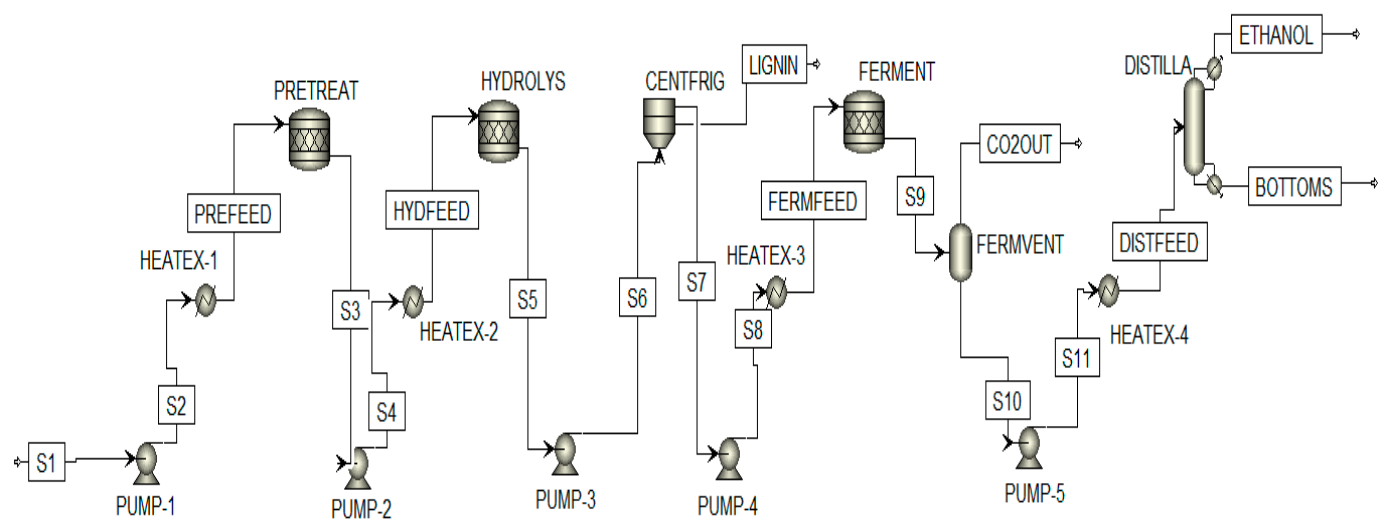

Figure 4. Aspen Plus simulation for fermentation.

The feed then flows into a second RStoic reactor, where hydrolysis takes place. The purpose of the HYDROLYS reactor is to achieve the maximum conversion of cellulose to glucose. Fractional conversion of cellulose is set to 0.99 and the unreacted solids are separated from the liquids in a downstream centrifugal separator. The liquid stream flows into PUMP-4 and HEATEX-3, where the conditions are set for the final reaction in the process. Then, a 0.95 fraction of glucose is converted to ethanol and carbon dioxide. Generally, enzymes would be used for the conversion, but since reaction kinetics are not included, the enzyme has not been modeled as a component in this simulation. Moreover, since this is purely a stoichiometric reaction, it is within reason to ignore enzymatic effects. The $\mathrm{CO}_{2}$ that is evolved is separated from the liquid product in FERMVENT.

Finally, the liquid mixture flows into PUMP-5 and HEATEX-4, where the conditions for the feed stream to the downstream distillation column are set. The DISTFEED stream operates at $30{ }^{\circ} \mathrm{C}$ and 2.432 bar and enters DISTILLA at stage 29. DISTILLA is modeled to have 45 stages, with a total differential pressure of $\sim 0.4$ bar across the internals. The top of the column is set to operate at 1.01 bar. The distillation column has a reboiler duty of $15 \mathrm{MW}$ and a reflux ratio of $6 \mathrm{~mol}$.

\subsection{Calculator Blocks for Pyrolysis and Gasification Models}

Since biomass is specified as a non-conventional solid, suitable FORTRAN statements are used within the calculator blocks to generate results. Each of the calculator blocks and their respective FORTRAN code are explained in the following subsections. Both the thermochemical models share 2 of the 3 calculator blocks, i.e., WATER calculator and DECOMP calculator. However, the gasification model has an additional AIR-FUEL calculator. Details of the FORTRAN statements are specified in Supplementary Information-Appendix A.

\subsubsection{WATER Calculator}

This block calculates the moisture that evolves from the wet biomass feed during the drying step.

\subsubsection{DECOMP Calculator}

This block calculates the composition of biomass during devolatilization. In this step, biomass is broken down into its elemental composition. The $\mathrm{w} t \%$ distribution is taken from biomass ultimate analysis.

\subsubsection{AIR-FUEL Calculator}

To help make things easy for users, this block performs simple calculations on the amount of air to be supplied to the gasification reactor (GASIF). 


\section{Results}

\subsection{Pyrolysis Results}

The summary of ASPEN Plus simulation results for the final product streams is given in Table 2. Additional stream details and details of all other equipment in the pyrolysis model can be found in Supplementary Information-Appendix B. For a biomass feed of $1000 \mathrm{~kg}, 199 \mathrm{~kg}$ of char and $797 \mathrm{~kg}$ of volatile matter are produced. Moisture makes up $30.8 \mathrm{wt} \%$, $\mathrm{CO}$ makes up $4.2 \mathrm{wt} \%$, and $\mathrm{CO}_{2}$ makes up $52.7 \mathrm{wt} \%$ of the syngas. The remaining $12.3 \mathrm{wt} \%$ of the gas is constituted by $\mathrm{H}_{2}$ and $\mathrm{CH}_{4}$, with small quantities of nitrogen $\left(\mathrm{N}_{2}\right)$, hydrogen sulfide $\left(\mathrm{H}_{2} \mathrm{~S}\right)$, and sulfur dioxide $\left(\mathrm{SO}_{2}\right)$. Trace amounts of other hydrocarbons are also obtained. Although the presence of other hydrocarbons is too small to be considered, a trend that is clearly seen is that longer hydrocarbon chains are less favored as they are less stable at higher temperatures. This is observed among the alkanes, alcohols, and aldehydes too. Benzene is the most stable molecule among the aromatic hydrocarbons and hence has the highest concentration. What is interesting is that all the $\mathrm{O}_{2}$ is used up but there is plenty of unreacted carbon and water. Ghorbannezhad et al. carried out fast pyrolysis of palm shell residue and obtained a maximum oil yield of $60 \mathrm{wt} \%$ when operating the reactor at $500{ }^{\circ} \mathrm{C}$ with a particle size of $600 \mu \mathrm{m}$ [53]. However, the oxygen component-rich bio-oil had a density that was much higher than heavy fuel oil but had a very low ash content. The study also concluded that at the mentioned operating conditions, the bio-oil was rich in phenols, with low char and gas yields, but produced maximum $\mathrm{H}_{2}$. From the results of this simulation study, it can be seen the content of bio-oil is very low. In reality, bio-oil will be condensed from the volatiles stream and biogas as well as bio-char will be present in a substantial amount. In fact, the quantity of bio-oil is expected to be greater than the quantity of biogas, as pyrolysis is designed to produce bio-oil. One reason for such a result is that devolatilization assumes that all the biomass is converted to its elemental form instead of forming the components in the proximate analysis. Following this, the products of the devolatilization step react in a Gibbs reactor, hence forming the products with the lowest Gibbs free energy and not favoring longer chain molecules. Bio-oil is a complex mix of heavy hydrocarbons which is not favored in the current system design.

Table 2. Pyrolysis volatiles and char stream results.

\begin{tabular}{ccc}
\hline Component & \multicolumn{2}{c}{ Mass Flow Rate (kg/h) } \\
& Gas Phase & CHAR \\
\hline BIOMASS & 0 & 0 \\
WATER & 246 & 0 \\
NITROGEN & 8 & 0 \\
HYDROGEN & 18 & 0 \\
CARBON-GRAPHITE & 0 & 199 \\
CARBON-MONOXIDE & 34 & 0 \\
CARBON-DIOXIDE & 420 & 0 \\
ASH & 0 & 0 \\
METHANE & 70 & 0 \\
HYDROGEN-SULFIDE & 2 & 0 \\
AMMONIA & 0 & 0 \\
Total Flow Rate & 797 & 199 \\
\hline
\end{tabular}

\subsection{Gasification Results}

Gasification yields no char as all the carbon reacts primarily with the oxygen in the air supply to form $\mathrm{CO}$ and $\mathrm{CO}_{2}$ in the GASIF reactor. Syngas in gas has no liquid fraction. Due to the very high operating temperature of the gasifier, all the bio-char reacts with the oxygen and water to form $\mathrm{CO}$ and $\mathrm{CO}_{2}$. In fact, most of the $\mathrm{CO}, \mathrm{CO}_{2}$, and $\mathrm{N}_{2}$ (from the air supplied to the GASIF) make up $90.7 \mathrm{wt} \%$ of the final product. A few observations like the pyrolysis model's results can be seen when it comes to hydrocarbons. This is mainly because RGibbs reactors are used for pyrolysis and 
gasification. Hence, the formation of favored products will follow a similar trend in both models. However, the presence of hydrocarbons can be neglected. The only fuel produced is $\mathrm{H}_{2}$. The resultant $56 \mathrm{~kg}$ of $\mathrm{H}_{2}$ per $1000 \mathrm{~kg}$ of biomass and $250 \mathrm{~kg}$ of air feed is a very low quantity to seem of any benefit. Surprisingly, almost no $\mathrm{CH}_{4}$ is produced. The high heating value (HHV) for syngas from the gasification simulation model is $12.8 \mathrm{MJ} / \mathrm{kg}$. According to Makkawi et al. [45], $\mathrm{HHV}$ is $17.2 \mathrm{MJ} / \mathrm{kg}$ for the fruit bunch, $16.5 \mathrm{MJ} / \mathrm{kg}$ for the leaf stem, and $18.9 \mathrm{MJ} / \mathrm{kg}$ for the palm leaves. A very high percentage of the energy content is retained in the syngas produced in this study. It is expected that biomass will convert to syngas with little to no bio-oil being produced. Samiran et al. suggested that the type of gasifier greatly affects the overall syngas yield and concluded that entrained flow gasifiers have the potential to yield the highest quality of low-tar syngas [54]. Moreover, a lot of attention must be paid toward the chemical composition of the biomass sample as it also plays a huge role in determining the quality of gas. According to the work of Khan et al., gasification of the oil palm kernel shell yielded a gas that was free of $\mathrm{CO}_{2}$ and rich in $\mathrm{H}_{2}$ and $\mathrm{CH}_{4}$, resulting in a heating value of $13.78 \mathrm{MJ} / \mathrm{Nm}^{3}$, where the biomass feedstock had a heating value of $18.46 \mathrm{MJ} / \mathrm{kg}$ [55]. The reported value by Khan was higher than the high heating value (HHV) and lower heating value (LHV) values obtained through this simulation study: $10.28 \mathrm{MJ} / \mathrm{m}^{3}$ and $9.38 \mathrm{MJ} / \mathrm{m}^{3}$. However, it was far greater than the heating value of syngas produced from the empty fruit bunch $\left(5.9 \mathrm{MJ} / \mathrm{Nm}^{3}\right)[56]$ and twice as much as the heating value of syngas produced from oil palm fronds $\left(4.8 \mathrm{MJ} / \mathrm{Nm}^{3}\right)$ [57]. The results summarized in Table 3 capture the final product stream composition obtained from the gasification simulation. Additional stream details and details of all other equipment in the pyrolysis model can be found in Supplementary Information-Appendix C. Unlike the results of the pyrolysis model, the devolatilization reaction coupled with the RGibbs reactor seems to yield desirable products, i.e., mainly syngas.

Table 3. Gasification syngas stream results.

\begin{tabular}{cc}
\hline Component & $\begin{array}{c}\text { Mass Flow Rate } \mathbf{( k g} / \mathbf{h}) \\
\text { Gas Phase }\end{array}$ \\
\hline Biomass & 0 \\
Water & 60 \\
Nitrogen & 231 \\
Hydrogen & 56 \\
Carbon-Monoxide & 809 \\
Carbon-Dioxide & 120 \\
Ash & 0 \\
Hydrogen-Sulfide & 2 \\
Total flow rate & 1279 \\
\hline
\end{tabular}

\subsection{Fermentation Results}

Looking at the mass balance, it can be observed that for $2000 \mathrm{~kg}$ feed of biomass, more than half the cellulose content is converted to bioethanol, i.e., $888 \mathrm{~kg}$ of cellulose yields $466 \mathrm{~kg}$ of ethanol. This conversion also requires a $5000 \mathrm{~kg} / \mathrm{h}$ supply of water, of which $3123 \mathrm{~kg}$ leaves as vapor along with the ethanol at the top of the column and $1769 \mathrm{~kg}$ leaves in the BOTTOMS. This indicates that there is an oversupply of water into the system, quite possibly because the distillation column has not been optimized. This raises the OpEX of the system drastically and wastes a lot of resources. Only $49 \mathrm{~kg}$ of glucose leaves the bottom of the column while none leaves the top, indicating that the system has been designed well for separation of the feed stream. Due to strong intermolecular bonds, water and ethanol form an azeotropic mixture, which makes it hard to separate them. Again, the separation can only be carried out effectively if the column is designed in a better manner. A better design will reduce the water supply to the system and result in less water leaving along with the ethanol; hence, a purer product, with $8 \mathrm{~kg}$ of water, $10 \mathrm{~kg}$ of ethanol, and $465 \mathrm{~kg}$ of $\mathrm{CO}_{2}$, leaves as vapor in the phase separator. What is of interest here is the $465 \mathrm{~kg}$ of $\mathrm{CO}_{2}$ which can be purified easily by condensing out the water and ethanol mixture. $\mathrm{CO}_{2}$ can then be sold or used in carbon capture and 
storage systems. After hydrolysis, only $6.4 \mathrm{~kg}$ of solids remains unconverted and is separated by the centrifugal separator. Additional stream details and details of all other equipment in the fermentation model can be found in Supplementary Information-Appendix D.

With a little more optimization in the design, fermentation can yield very promising results. The low operating temperatures and pressures add to its attractiveness. A better column would allow for effective separation and lower feed of water, i.e., minimizing the amount of water leaving the top of the column.

\subsection{Heat Balance Analysis}

The best method of assessing the maximum recoverable heat content would be through pinch analysis. Due to time constraints, this was not possible, and very basic steps were taken to check for potential heat recovery from the models. The system duty results for pyrolysis and gasification presented here are for a 1 tonne feed of date palm waste. On the other hand, the results for fermentation are for a 2 tonne feed. Thermochemical processes involve operations at very high temperatures. This makes heat recovery an integral step for increasing the overall system efficiency. For pyrolysis, the air feed to the drier is heated to $50{ }^{\circ} \mathrm{C}$ using syngas in HEATX-1. The air drier is designed to mimic convective drying. As such, air at $50^{\circ} \mathrm{C}$ is reasonable. Biomass in IN-DRY only experiences a temperature of $26^{\circ} \mathrm{C}$. This is well below the intended drying temperature. Moreover, VOL-C leaves at $496^{\circ} \mathrm{C}$ and this allows for further heat recovery into the process. Essentially, $1.717 \mathrm{MJ}$ is required to operate DEVOL at $200^{\circ} \mathrm{C}$. On the other hand, pyrolysis is exothermic. Net heat duty on the PYROL reactor is $-1.526 \mathrm{MJ}$. A total of $0.191 \mathrm{MJ}$ of energy input is required to carry out pyrolysis of $1000 \mathrm{~kg} / \mathrm{h}$ date palm waste feed.

In the first approach, HEATREC1 was added to recover heat from the hot VOLS-H stream, as seen in Figure 5. The purpose of HEATREC1 is to heat up the dry biomass and recover heat from VOLS-C. This will give us an idea of the energy savings on the DEVOL reactor. Although the process requirement is to achieve a PYROL temperature of $200{ }^{\circ} \mathrm{C}$, initially, the maximum possible attainable temperature for BOTTOMS was checked. The stream was heated from 26 to $320^{\circ} \mathrm{C}$ via HEATREC1. This gives an idea of how much heat can potentially be recovered from VOLS-C. Next, BOTTOMSH temperature was set to $200^{\circ} \mathrm{C}$ in HEATREC1. Moreover, DEVOL must still be supplied with $1.637 \mathrm{MJ} /$ tonne of the biomass of heat to carry out devolatilization. This is a mere $80 \mathrm{~kJ}$ of energy recovery. However, it is known that a lot more heat can be recovered as VOLS-CC leaves at $198^{\circ} \mathrm{C}$.

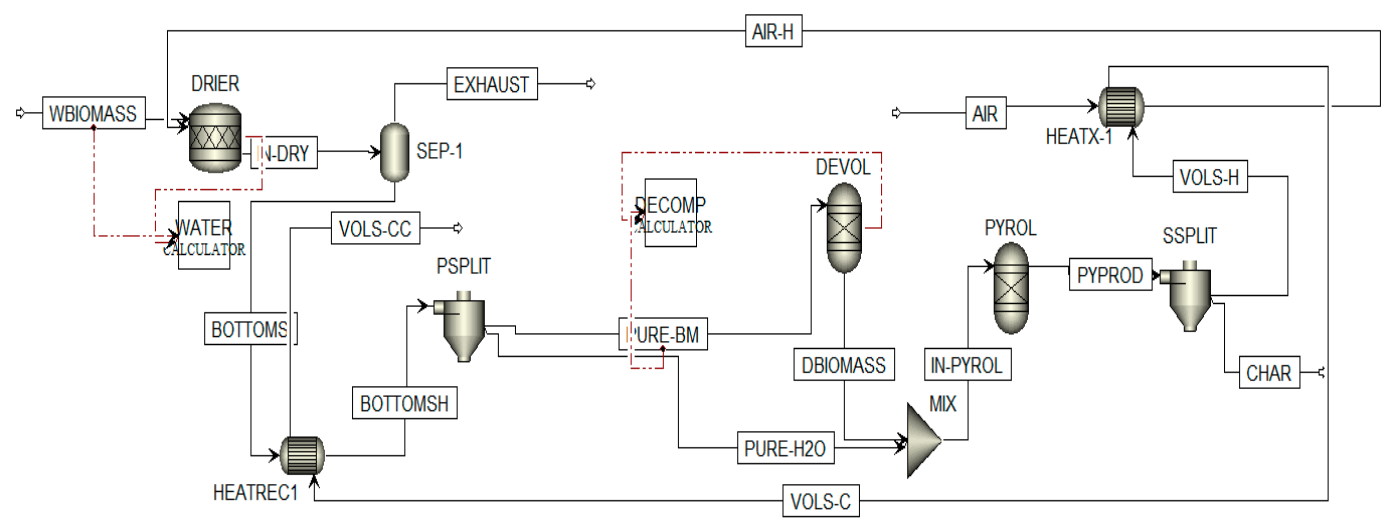

Figure 5. Heat recovery for pyrolysis (first attempt).

The second approach was to change the location of HEATREC1 to upstream of the PYROL reactor, as displayed in Figure 6. PYROLH was heated to $400{ }^{\circ} \mathrm{C}$ and VOLS-CC left at $119^{\circ} \mathrm{C}$, bringing the net duty of PYROL to $1.68 \mathrm{MJ} /$ tonne biomass, i.e., $0.154 \mathrm{MJ}$ of excess useable energy. Note that since HEATREC1 is relocated, DEVOL net duty returns to $1.717 \mathrm{MJ}$; however, this time, an additional $0.074 \mathrm{MJ}$ of energy is recovered per tonne of biomass. It is also worth noting that VOLS-CC leaves at 
$119^{\circ} \mathrm{C}$, which is lower than the previous case. If the previous case was chosen as the desired option, then another heat exchanger would have to be incorporated to further recover heat from VOLS-CC, in turn driving up the CapEx.

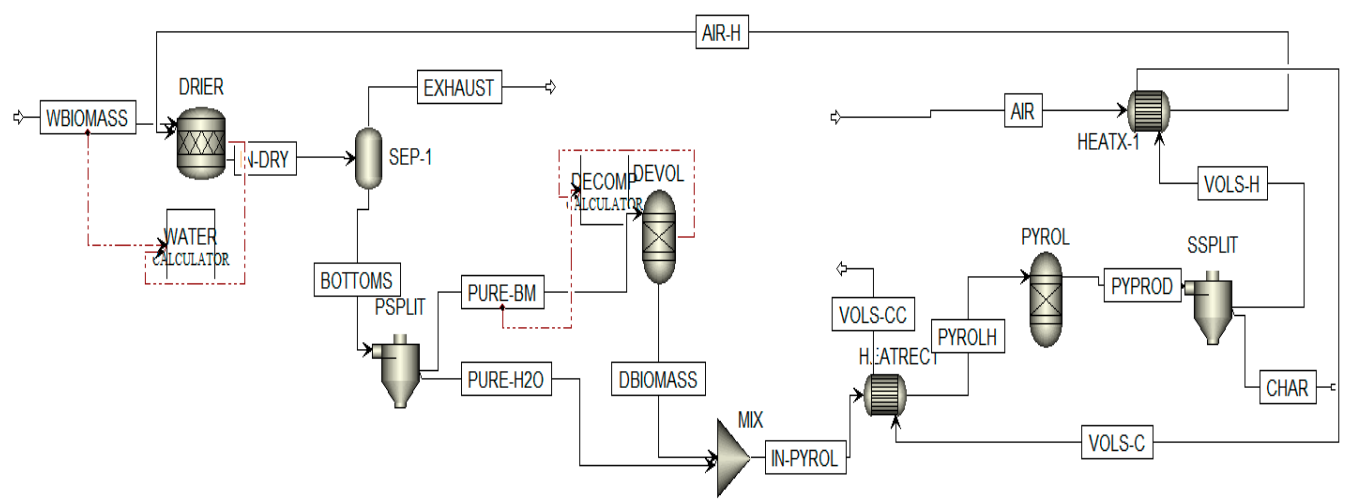

Figure 6. Heat recovery for pyrolysis (final model).

As discussed in the pyrolysis model, at first, HEATREC1 was placed upstream of PSPLIT. However, due to poor heat recovery, HEATREC1 was relocated. Through observation of the system layout and noticing the stark similarities in the two processes, it can be concluded that the same system constraints can be applied to this system as well. Hence, HEATREC was not placed before PSPLIT. Another reason to avoid this equipment configuration is because, in gasification, GASIF is operated at $900{ }^{\circ} \mathrm{C}$ and so the syngas in VOLS-H leaves at a much higher temperature.

In Figure 7, HEATREC1 is placed upstream of the GASIF reactor. In this model, the heat requirement for DEVOL is the same as that in the pyrolysis model because the process remains unchanged up till the reactor. Without heat recovery, the net duty of GASIF is $-0.591 \mathrm{MJ}$, and VOLS-C is $792{ }^{\circ} \mathrm{C}$. After including HEATREC1, VOLS-CC was $154^{\circ} \mathrm{C}$ and GASIF net duty increased by 0.321 to $0.992 \mathrm{MJ}$. Biomass was fed to the GASIF reactor at $780^{\circ} \mathrm{C}$.

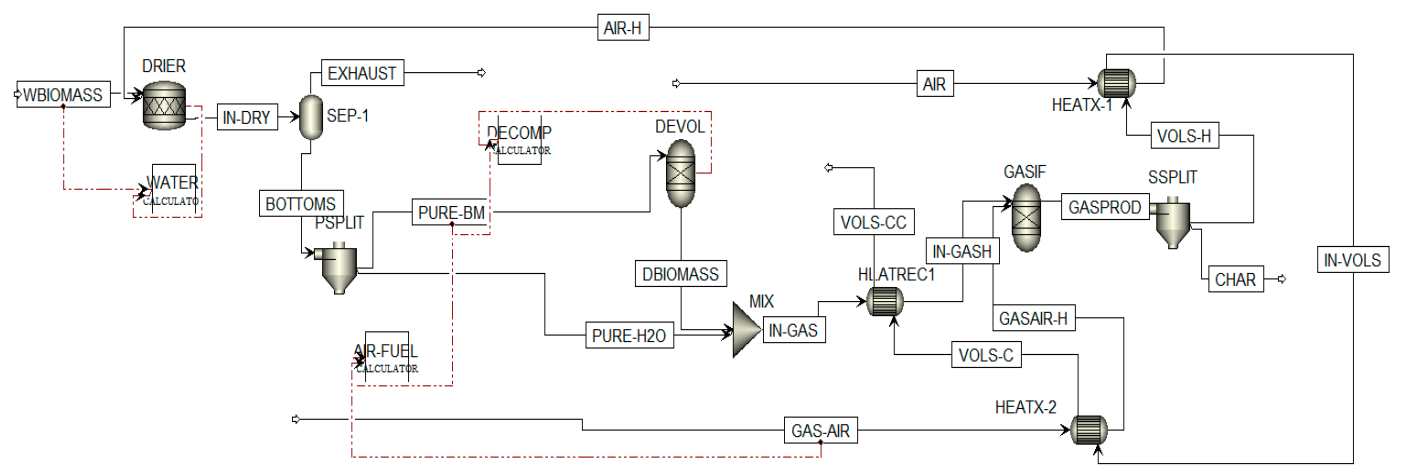

Figure 7. Heat recovery for gasification.

The results indicate that there are many areas that need to be addressed. A summary of the equipment net duty is presented in Table 4 and suggestions for improvement for the model are presented in the following section.

For the purpose of an energy balance, PUMP-2 can be assumed to be a turbine and the negative energy value indicates energy that is recovered. As discussed earlier, reboiler duty can be lowered when the column is optimized. What is interesting to observe from these data is that only water and cellulose were reacted to form glucose in the pretreatment and hydrolysis steps; however, the reaction in the HYDROLYS reactor is slightly exothermic but pretreatment was highly endothermic. The high-pressure steam might not be favorable for the formation of glucose. The areas for energy recovery include: optimizing the distillation column to produce maximum bioethanol, using a turbine in the pace of 
PUMP-2 to recover energy from high-pressure steam exiting the PRETREAT reactor, and utilizing the heat from streams S3, S5, S9, and BOTTOMS to heat up other internal streams.

Table 4. Summary of energy requirements in the fermentation model.

\begin{tabular}{cc}
\hline Equipment & Net Duty (Watts) \\
\hline Pumps & 3618 \\
Heat Exchangers & 15,415 \\
Pretreat & 24,967 \\
Hydrolys & -3807 \\
Ferment & $-76,953$ \\
Distilla Reboiler & $15,000,000$ \\
Net Total & $14,963,240$ \\
\hline
\end{tabular}

Improving process economics via energy integration is a common industry practice. Shemfe et al. [48] showed the benefits of using pinch analysis to reduce $\mathrm{CO}_{2}$ emissions (up to $90 \%$ ) and reduce energy consumption within a biofuel refinery that involves bio-oil hydroprocessing and bio-oil steam reforming [58]. Tong et al. [49] used artificial intelligence to investigate the potential of biofuel incorporation into crude oil processing, co-processing with refinery intermediates, and blending with finished products [59]. The study improves the derived value from the entire biofuel and fossil fuel supply chain, thereby enhancing process economics. In a similar manner, artificial intelligence can also be used to integrate waste heat from several untapped sources in a fossil fuel refinery. Marbe and Harvey [50] discussed the potential of integrating renewable energy systems along with biofuel gasification processes into a natural gas combined cycle for combined heat and power [60]. Salman et al. [51] carried out a techno-economic assessment of using waste heat from a bio-fueled combined heat and power (CHP) plant to power three different gasifiers and generate biomethane [61]. Ideas from this study can be used to integrate biomethane production and gasifier operation from heat generated by fossil fuel-based CHP systems. Andersson et al. [52] recovered waste heat from an oil refinery and used it to power an algae-driven biorefinery [62]. The assessment was carried out by performing simple material and heat balances around the system of interest. Pinch analysis was conducted to determine minimum utility requirements and the most effective operating points and avenues for $\mathrm{CO}_{2}$ reduction were investigated. Moreover, because the biorefinery was integrated with an oil refinery, this allowed for $\mathrm{H}_{2}$ generation via steam reforming, which was used as a process fuel (heating the boiler) and considered to be more efficient than electrolysis. Improving the biofuel value chain is just as important as heat recovery. Dyk et al. [53] suggested that the co-processing of biofuels in the fossil fuel industry will immensely help with curbing greenhouse gas emissions and enable refiners to overcome several economic challenges $[63,64]$. Though biofuel processing is a complex process and advancement in this sector has been slow, the current infrastructure is completely capable of ensuring that the co-processing is feasible, which will eventually lead to the replacement of petroleum-derived products with bio-based products.

\subsection{Simulation Economic Evaluation}

The terms "profit" and "expenditure" in this study refer to the monetary value of running the process, i.e., profit $/$ expenditure $=$ cost of running the process (net system duty) - the cost of fuels. Table 5 indicates a few spot prices for January 2020, taken from the US Department of Energy Alternative Fuel Price Report for 2020 [34]. The cost of hydrogen is taken as the average cost of 2.5-6.8 USD $/ \mathrm{kg}$ [65]. A simple cost analysis was performed, taking into account the cost of energy demand by the process and fuel prices in Table 5, for which the results are displayed in Table 6. It is seen that both pyrolysis and gasification are profitable due to the very low process energy requirement, which is reduced further through optimization. 
Table 5. Fuel prices from the US Department of Energy for Jan 2020 [64].

\begin{tabular}{ccc}
\hline Fuel & Unit Price & Unit of Measure \\
\hline Biodiesel (B20) & 2.89 & $\$ /$ gallon \\
Biodiesel (B99-B100) & 3.72 & $\$ /$ gallon \\
Electricity & 0.13 & $\$ / \mathrm{kWh}$ \\
Ethanol (E85) & 2.28 & $\$ /$ gallon \\
Natural Gas (CNG) & 2.19 & \$/gallon gasoline equivalent \\
Liquefied Natural Gas & 2.77 & \$/diesel gasoline equivalent \\
Propane & 2.79 & $\$ /$ gallon \\
Gasoline & 2.59 & $\$ /$ gallon \\
Diesel & 3.05 & $\$ /$ gallon \\
Hydrogen & 4.65 &
\end{tabular}

Table 6. A brief economic evaluation.

\begin{tabular}{|c|c|c|c|c|c|c|c|c|c|}
\hline & \multicolumn{3}{|c|}{ Pyrolysis } & \multicolumn{3}{|c|}{ Gasification } & \multicolumn{3}{|c|}{ Fermentation } \\
\hline & Quantity & Unit & $\begin{array}{c}\text { \$/tonne of } \\
\text { Biomass }\end{array}$ & Quantity & UOM & $\begin{array}{c}\text { \$/tonne of } \\
\text { Biomass }\end{array}$ & Quantity & UOM & $\begin{array}{c}\text { \$/tonne of } \\
\text { Biomass }\end{array}$ \\
\hline Net Duty & & $\mathrm{kJ} /$ tonne & & & $\mathrm{kJ} /$ tonne & & & $\mathrm{kJ} /$ tonne & \\
\hline W/O Heat & 191 & biomass & 25 & 1126 & biomass & 146 & 7481.5 & biomass & 973 \\
\hline Recovery & & feed & & & feed & & & feed & \\
\hline Net Duty & & $\mathrm{kJ} /$ tonne & & & $\mathrm{kJ} /$ tonne & & & & \\
\hline With Heat & 37 & biomass & 5 & 725 & biomass & 94 & - & - & - \\
\hline $\begin{array}{l}\text { Recovery } \\
\text { Hydrogen }\end{array}$ & & feed & & & feed & & & & \\
\hline Produced & 18 & $\mathrm{~kg}$ & 84 & 56 & $\mathrm{~kg}$ & 260 & - & - & - \\
\hline $\begin{array}{l}\text { Methane } \\
\text { Produced }\end{array}$ & 70 & $\mathrm{~kg}$ & 689 & 0 & $\mathrm{~kg}$ & 0 & - & - & - \\
\hline $\begin{array}{l}\text { Bio-Char } \\
\text { Produced }\end{array}$ & 199 & $\mathrm{~kg}$ & - & 0 & $\mathrm{~kg}$ & - & - & - & - \\
\hline $\begin{array}{c}\text { Water } \\
\text { Produced }\end{array}$ & 246 & $\mathrm{~kg}$ & - & 60 & $\mathrm{~kg}$ & - & - & - & - \\
\hline Bioethanol & - & - & - & - & - & - & 233 & $\mathrm{~kg}$ & 209 \\
\hline $\begin{array}{l}\text { Fuel Yield } \\
\text { per kg Feed }\end{array}$ & 8.8 & $\%$ & - & 5.6 & $\%$ & - & 23.3 & $\%$ & - \\
\hline $\begin{array}{l}\text { Process } \\
\text { Cost }(\$)\end{array}$ & - & - & 768 & - & - & 166 & - & - & -763 \\
\hline
\end{tabular}

Pyrolysis seems to be a lot more profitable because of the low operating temperature, i.e., low system net duty, and the cost of fuel. On the other hand, fermentation yields bioethanol, which can be used as a blend (E85) and is worth USD 209 (for a $1000 \mathrm{~kg}$ feed of biomass). The final product value of fermentation is much more valuable than pyrolysis and gasification, but it is the distillation column energy requirement that makes the profit void, i.e., the cost of running the system outweighs the value of fuel if priced as per Table 5. The pyrolysis and gasification results in Table 6 are for a $1000 \mathrm{~kg}$ biomass feed. The simulations for fermentation were carried out for a date palm waste feed of $2000 \mathrm{~kg}$ ( $888 \mathrm{~kg}$ cellulose); however, the results are calculated (scaled linearly) per tonne of biomass to ensure fair comparison with pyrolysis and gasification. Through a techno-economic, energetic, and environmental comparison of biochemical and thermochemical routes using Pinus patula, it was observed that the synthesis cost of bioethanol was much lower and the associated energy efficiency was much higher (by $16.1 \%$ ) than for biomass gasification $[65,66]$. Another point to keep in mind is that while pyrolysis seems to be the most favored, i.e., gives the highest monetary return per tonne of biomass, the product yields for pyrolysis are not a reflection of what ideally should happen. Pyrolysis is a process which is designed to produce more bio-oil and less biogas, which is not the case here. As is evident from Table 6, pyrolysis and gasification show great results for up-scaling. However, this is not the case for fermentation. The relationship between the system's net duty and the cost of fuel was evaluated for the fermentation process and is presented in Table 7. 
Table 7. Fermentation breakeven analysis for one tonne biomass feed.

\begin{tabular}{cccc}
\hline $\begin{array}{c}\text { Net Duty } \\
\text { kJ/tonne Biomass }\end{array}$ & $\begin{array}{c}\text { Process Cost } \\
\text { \$/tonne Biomass }\end{array}$ & Cost of Fuel \$/gal & Cost of Fuel \$/L \\
\hline 7481.5 & 763 & 10.60 & 2.80 \\
7000 & 701 & 9.91 & 2.62 \\
6500 & 636 & 9.21 & 2.43 \\
6000 & 571 & 8.50 & 2.25 \\
5500 & 506 & 7.79 & 2.06 \\
5000 & 441 & 7.08 & 1.87 \\
4500 & 376 & 6.37 & 1.68 \\
\hline
\end{tabular}

At the simulation operating conditions, i.e., system net duty of $7481.5 \mathrm{~kJ} /$ tonne biomass, bioethanol is to be priced at $2.80 \mathrm{USD} / \mathrm{L}$, which is outside of the acceptable CapEX breakeven cost of 0.8-2.4 USD/L [67]. However, the breakeven fuel price can be made acceptable by reducing the system's net duty to $6500 \mathrm{~kJ} /$ tonne biomass.

Going forward, a good idea would be to compare the fermentation model's results to another research article. This will indicate exactly how the designed process in this study compares with other models. A study by Olba-Ziety et al. [68] focuses on the commercial evaluation of bioethanol production from sugar beets and is compared with the results of this study [68]. The comparison is presented in Table 8, from which it is seen that by reducing the net system duty to $6500 \mathrm{~kJ} /$ tonne biomass and assuming $30 \%$ conversion of hemicellulose content in the biomass, which comes up to approx. $73 \mathrm{~kg}$ of the $1000 \mathrm{~kg}$ feed, a breakeven bioethanol fuel price of $1.85 \$ / \mathrm{L}$ can be achieved. This is in close agreement with the price presented in the work by Olba-Ziety et al. [68]. The breakeven price is defined as the price at which bioethanol must be sold in order to breakeven with system net duty and estimated CapEX costs. The price was calculated by using the goal seek function in Microsoft Excel and setting the process cost to zero by varying the cost of bioethanol (E85).

Table 8. Checking fermentation economic feasibility.

\begin{tabular}{cccc}
\hline & Literature [68] & $\begin{array}{c}\text { This Study } \\
\text { @ 7481.5 kJ/tonne }\end{array}$ & $\begin{array}{c}\text { This Study } \\
\text { @ 6500 kJ/tonne }\end{array}$ \\
\hline Biomass Feedstock & Sugar beets & $\begin{array}{c}\text { Date Palm Waste } \\
\text { (Cellulose) }\end{array}$ & $\begin{array}{c}\text { Date Palm Waste } \\
\text { (Cellulose + Hemicellulose) }\end{array}$ \\
Feed Quantity & $83,333 \mathrm{~kg}$ & $1000 \mathrm{~kg}$ & $1000 \mathrm{~kg}$ \\
\% Sugar & $66.8 \%$ & $44.4 \%$ & $68.7 \%$ \\
Sugar/Fermentable Content & $55,666 \mathrm{~kg}$ & $444 \mathrm{~kg}$ & $687 \mathrm{~kg}$ \\
Bioethanol Produced & $6227 \mathrm{~kg}$ & $233 \mathrm{~kg}$ & $306 \mathrm{~kg}$ \\
Bioethanol Yield & $11 \%$ & $52 \%$ & $45 \%$ \\
(From Sugars Only) & $1.8 \$ / \mathrm{L}$ & $2.80 \$ / \mathrm{L}$ & $1.85 \$ / \mathrm{L}$ \\
Breakeven Fuel Price & & &
\end{tabular}

To breakeven with the CapEX and system energy requirement, the net duty must be reduced to $6500 \mathrm{~kJ} /$ tonne biomass (this can be achieved by system optimization) and 30\% of the unused hemicellulose has to be converted as well. Specifically, 30\% hemicellulose conversion of $1000 \mathrm{~kg}$ of biomass is equivalent to $73 \mathrm{~kg}$ of bioethanol. These minor adjustments will justify the bioethanol (E85) selling price of $1.85 \mathrm{USD} / \mathrm{L}$.

The $30 \%$ conversion of hemicellulose is also reasonable since in the initial breakeven calculation (and in the model), only cellulose was considered, with a fuel conversion of $45 \%$ with respect to the total fermentable solids. What also needs to be considered is that ethanol and water form an azeotropic mixture; hence, not just the distillation column but the method needs to be reviewed and updated as per industry practices. However, Table 8 gives an idea of how much optimization would be required for fuel prices to be competitive. Since this model does not use $70 \%$ of the hemicellulose and all the lignin, another way to overcome process inefficiencies and enforce a waste management strategy 
would be by processing the remaining organic matter into biomethane via anaerobic digestion [69]. In a study by Ghofrani-Isfahani [70] on anaerobic digestion of wheat straw, it was found that $\mathrm{TiO}_{2}$ nanoparticles coated with $\mathrm{Fe}_{2} \mathrm{O}_{3}$ and $\mathrm{NiO}$ led to a $21.1 \%$ and $29 \%$ increase in methane production, respectively. Pansang et al. [61] studied the effects of pretreating oil palm empty fruit bunch and palm fiber to hot compressed water by maintaining the operating temperature between 150 and $200{ }^{\circ} \mathrm{C}$ and operating pressure of 30 bars for several time intervals and the process did not involve the use of any chemicals [71]. Through this environment-friendly pretreatment method, the authors achieved ethanol yields of $0.37 \mathrm{~g} / \mathrm{g}$ glucose and $0.40 \mathrm{~g} / \mathrm{g}$ glucose for the empty fruit bunch and palm fiber, respectively. Glucose was calculated on the basis of cellulose content (69.3\%) in the lignocellulosic sample. It was also observed that at higher temperatures, the cellulose content increased due to hemicellulose removal and lignin degradation. From the results presented in Table 8, it can be seen that the ethanol yield was $0.52 \mathrm{~g} / \mathrm{g}$ glucose when considering glucose derived from cellulose alone.

Biofuels are considered to be promising transportation fuels and have a huge impact on the social, economic, and environmental aspects [72,73]. Moreover, energy recovery from organic waste has become the center of attention in recent years as population growth is directly linked to more food waste and crop residue [74]. The development of large-scale biofuel processing also provides a safety cushion for agricultural price volatility induced by supply-side shocks [75]. The work presented in this study aims to utilize waste biomass by generating energy and other valuable fuels to empower the country's economy and spark the shift to a dynamic energy mix by reducing dependence on fossil fuels. The study also compares three different pathways for biofuel synthesis and hence paints a fair picture of how thermochemical and biochemical processes compare to each other.

\section{Conclusions}

This work reports the simulation results of the pyrolysis, gasification, and fermentation processes for biofuel synthesis from date waste in UAE. The system duty for 1 tonne of date palm waste was found for each of the processes; pyrolysis was $37 \mathrm{~kJ} /$ tonne, gasification was $725 \mathrm{~kJ} /$ tonne, and fermentation was $7481.5 \mathrm{~kJ} /$ tonne. HHV of syngas from the gasification simulation model is $12.8 \mathrm{MJ} / \mathrm{kg}$. From the results of this study, it is seen that the syngas produced through thermochemical pathways is quite low in valuable fuels and relatively high in $\mathrm{CO}_{2}$ and $\mathrm{CO}$ content. Syngas $\mathrm{HHV}$ can be maximized by converting the $\mathrm{CO}_{2}$ and $\mathrm{H}_{2} \mathrm{O}$ to $\mathrm{CO}, \mathrm{CH}_{4}$, and $\mathrm{H}_{2}$ and by reducing pollutants/toxins such as $\mathrm{NO}_{x}$ and $\mathrm{H}_{2} \mathrm{~S} . \mathrm{CO}_{2}$ separation is necessary and several common industry practices have been suggested to increase fuel value and make $\mathrm{CO}_{2}$ marketable as well. Pyrolysis did not generate the expected results since an RGibbs reactor was used and a low quantity of bio-oil was recovered. The high net duty for fermentation was governed by the high reboiler duty (15 MW). However, biofuel yield was the highest for fermentation and further optimization with appropriate heat recovery will improve the overall process' feasibility, making it attractive for the biofuel synthesis process. Operational costs were evaluated by comparing the system duty and the price of synthesized biofuels. Pyrolysis and gasification were profitable since fuel value outweighed the system duty cost, yielding USD 768 and USD 166, respectively, per tonne of date palm waste processed. Fermentation, on the other hand, was not profitable, since system duty cost was higher than bioethanol value. Therefore, the process required USD 763 expenditure to process 1 tonne of date palm waste. The fermentation model shows a lot of promise since it had the highest fuel yield of $23.3 \%$ for an equivalent feed in comparison to the thermochemical processes. The fermentation model was assessed further, and it was found that it is possible to breakeven on system CapEx and duty costs by decreasing system net duty to $6500 \mathrm{~kJ} /$ tonne biomass and converting 30\% hemicellulose to fuel as well. This allows for a lower bioethanol selling price of $1.85 \mathrm{USD} / \mathrm{L}$.

The models reported in this work are useful to upscale the processes. The adoption of biofuels depends on the economic benefit in comparison to other energy sources. By addressing the nation's policies related to energy security, rural development, and mitigation of climate change, investments into the biofuels market can be encouraged. 
In this work, the total of the pyritic, sulfate, and organic components were set equal to the total sulfur content mentioned in the ultimate analysis. Since it is quite difficult to find sulfur composition categorized as pyritic, sulfate, and organic, the sum of the three was set to the total sulfur composition in the ultimate analysis.

Author Contributions: Conceptualization, A.A.-O., M.A. and M.T; methodology, R.M., A.A.-O., M.A. and M.T.; validation, R.M. and M.A.; formal analysis, R.M., A.A.-O. and M.A.; investigation, R.M., A.A.-O. and M.A.; resources, A.A.-O. and M.T.; writing-original draft preparation, R.M., A.A.-O., M.A. and M.T.; writing-review and editing, R.M., A.A.-O., M.A. and M.T.; visualization, A.A.-O., M.A. and M.T.; supervision A.A.-O. and M.A. All authors have read and agreed to the published version of the manuscript.

Funding: This research received no external funding.

Conflicts of Interest: The authors declare no conflict of interest.

\section{Appendix A}

Table A1. FORTRAN statements for calculating moisture (WATER Calculator Block).

\begin{tabular}{cc}
\hline & FORTRAN Statements \\
& H2ODRY $=\mathbf{5 . 0}$ \\
Fariable & Description \\
H2ODRY & Wt $\%$ of moisture in dry biomass. Value is set to $5 \%$ as it is expected that even after drying, \\
H2OIN & biomass will retain some of its moisture content \\
FCONV & Wt $\%$ of moisture in wet biomass \\
\hline
\end{tabular}

Table A2. FORTRAN statements for devolatilization yields (DECOMP Calculator Block).

\begin{tabular}{|c|c|}
\hline \multicolumn{2}{|r|}{ FORTRAN Statements } \\
\hline \multicolumn{2}{|r|}{ FACT $=(100-$ WATER $) / 100$} \\
\hline \multicolumn{2}{|r|}{$\mathrm{H} 2 \mathrm{O}=((($ WATER/100 $)))$} \\
\hline \multicolumn{2}{|r|}{$\mathrm{ASH}=((\mathrm{ULT}(1) / 100) * \mathrm{FACT})$} \\
\hline \multicolumn{2}{|r|}{$\mathrm{CARB}=((\mathrm{ULT}(2) / 100) * \mathrm{FACT})$} \\
\hline \multicolumn{2}{|r|}{$\mathrm{H} 2=((\mathrm{ULT}(3) / 100) * \mathrm{FACT})$} \\
\hline \multicolumn{2}{|r|}{$\mathrm{N} 2=((\mathrm{ULT}(4) / 100) * \mathrm{FACT})$} \\
\hline \multicolumn{2}{|r|}{$\mathrm{CL} 2=((\mathrm{ULT}(5) / 100) * \mathrm{FACT})$} \\
\hline \multicolumn{2}{|r|}{ SULF $=((\mathrm{ULT}(6) / 100) * \mathrm{FACT})$} \\
\hline \multicolumn{2}{|r|}{$\mathrm{O} 2=((\mathrm{ULT}(7) / 100) * \mathrm{FACT})$} \\
\hline Variable & Description \\
\hline FACT & Factor to convert the ultimate analysis to a wet basis \\
\hline ULT & Vector to store biomass ultimate analysis component data \\
\hline WATER & Water content in dry biomass taken from proximate analysis \\
\hline $\mathrm{H} 2 \mathrm{O}$ & Calculated $w t \%$ of water exiting DEVOL \\
\hline ASH & Calculated $w \mathrm{t} \%$ of ash exiting DEVOL \\
\hline CARB & Calculated wt\% of carbon exiting DEVOL \\
\hline $\mathrm{H} 2$ & Calculated $w \mathrm{t} \%$ of hydrogen exiting DEVOL \\
\hline $\mathrm{N} 2$ & Calculated $w \mathrm{t} \%$ of nitrogen exiting DEVOL \\
\hline CL2 & Calculated $w \mathrm{t} \%$ of chlorine exiting DEVOL \\
\hline SULF & Calculated wt\% of sulfur exiting DEVOL \\
\hline $\mathrm{O} 2$ & Calculated $w t \%$ of oxygen exiting DEVOL \\
\hline
\end{tabular}


Table A3. FORTRAN statements for calculating air feed to gasifier (AIR-FUEL Calculator Block).

\begin{tabular}{cc}
\hline & FORTRAN Statements \\
\hline Variable & AIR $=\mathbf{0 . 3}{ }^{*}$ FUEL \\
AIR & Description \\
FUEL & Mass flow of air to be fed to the gasifier \\
Dry biomass in stream PURE-BM
\end{tabular}

\section{Appendix B}

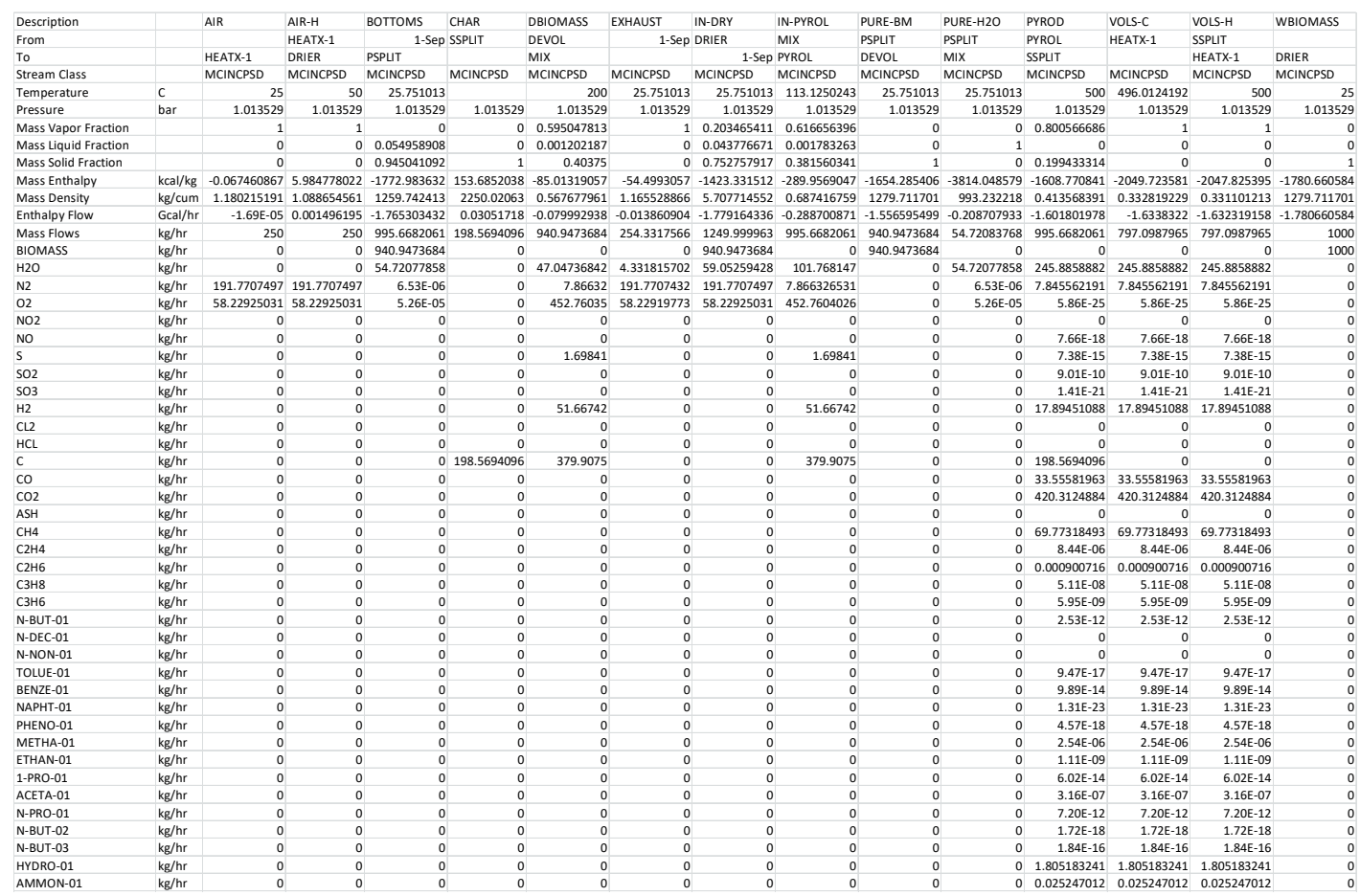

Figure A1. Pyrolysis stream results.

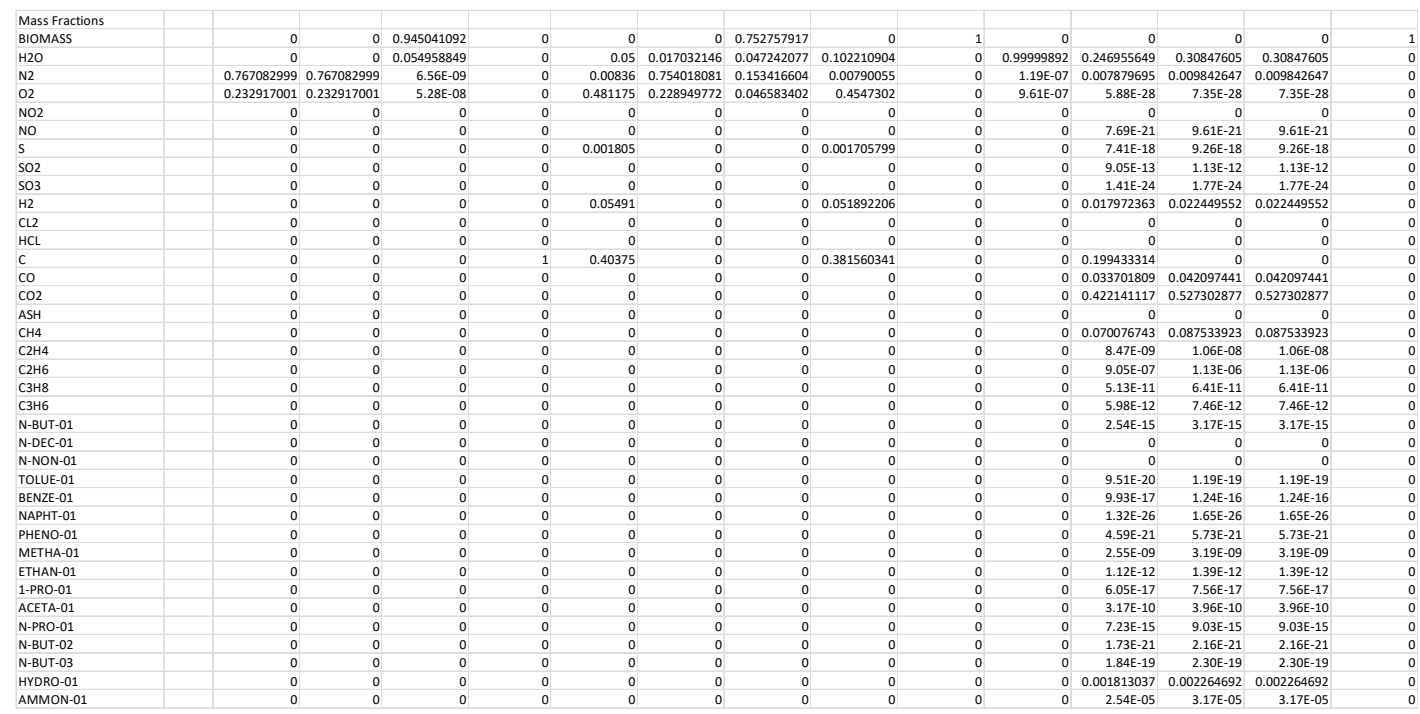

Figure A2. Pyrolysis stream results (mass fractions). 


\begin{tabular}{|c|c|}
\hline Name & HEATX-1 \\
\hline Hot side property method & PENG-ROB \\
\hline Hot side use true species approach for electrolytes & YES \\
\hline Hot side free-water phase properties method & STEAM-TA \\
\hline Hot side water solubility method & 3 \\
\hline Cold side property method & PENG-ROB \\
\hline Cold side use true species approach for electrolytes & YES \\
\hline Cold side free-water phase properties method & STEAM-TA \\
\hline Cold side water solubility method & 3 \\
\hline Exchanger specification & 50 \\
\hline Minimum temperature approach [C] & 1 \\
\hline Inlet hot stream temperature [C] & 500 \\
\hline Inlet hot stream pressure [bar] & 1.013529 \\
\hline Inlet hot stream vapor fraction & 1 \\
\hline Outlet hot stream temperature [C] & 496.012419 \\
\hline Outlet hot stream pressure [bar] & 1.013529 \\
\hline Outlet hot stream vapor fraction & 1 \\
\hline Inlet cold stream temperature [C] & 25 \\
\hline Inlet cold stream pressure [bar] & 1.013529 \\
\hline Inlet cold stream vapor fraction & 1 \\
\hline Outlet cold stream temperature [C] & 50 \\
\hline Outlet cold stream pressure [bar] & 1.013529 \\
\hline Outlet cold stream vapor fraction & 1 \\
\hline Heat duty [Gcal/hr] & 0.001513055 \\
\hline Calculated heat duty [Gcal/hr] & 0.001513055 \\
\hline Required exchanger area [sqm] & 0.004496302 \\
\hline Actual exchanger area [sqm] & 0.004496302 \\
\hline UA [cal/sec-K] & 0.912834696 \\
\hline LMTD (Corrected) [C] & 460.426319 \\
\hline LMTD correction factor & 1 \\
\hline
\end{tabular}

Figure A3. Pyrolysis heat exchanger results. 


\begin{tabular}{|c|c|}
\hline Name & DRIER \\
\hline Property method & PENG-ROB \\
\hline Use true species approach for electrolytes & YES \\
\hline Free-water phase properties method & STEAM-TA \\
\hline Water solubility method & 3 \\
\hline Specified pressure [bar] & 1.013529 \\
\hline Specified temperature $[\mathrm{C}]$ & 150 \\
\hline Outlet temperature [C] & 25.751013 \\
\hline Outlet pressure [bar] & 1.013529 \\
\hline Calculated heat duty [Gcal/hr] & 0 \\
\hline Net heat duty [Gcal/hr] & 0 \\
\hline Calculated vapor fraction & 0.745676291 \\
\hline Name & 1-Sep \\
\hline Property method & PENG-ROB \\
\hline Use true species approach for electrolytes & YES \\
\hline Free-water phase properties method & STEAM-TA \\
\hline Water solubility method & 3 \\
\hline Temperature [C] & 150 \\
\hline Pressure [bar] & 1.013529 \\
\hline Specified heat duty [Gcal/hr] & 0 \\
\hline Outlet temperature [C] & 25.751013 \\
\hline Outlet pressure [bar] & 1.013529 \\
\hline Vapor fraction & 0.745676291 \\
\hline Heat duty [Gcal/hr] & 0 \\
\hline Net duty [Gcal/hr] & 0 \\
\hline
\end{tabular}

Figure A4. Pyrolysis drier and separator results. 


\begin{tabular}{|l|r|}
\hline Name & DEVOL \\
\hline Property method & PENG-ROB \\
\hline Use true species approach for electrolytes & YES \\
\hline Free-water phase properties method & STEAM-TA \\
\hline Water solubility method & 3 \\
\hline Specified pressure [bar] & 1.013529 \\
\hline Specified temperature [C] & 200 \\
\hline Outlet temperature [C] & 200 \\
\hline Outlet pressure [bar] & 1.013529 \\
\hline Calculated heat duty [Gcal/hr] & 1.47660256 \\
\hline Net heat duty [Gcal/hr] & 1.47660256 \\
\hline Calculated vapor fraction & 0.999172994 \\
\hline & \\
\hline Name & PYROL \\
\hline Property method & PENG-ROB \\
\hline Use true species approach for electrolytes & YES \\
\hline Free-water phase properties method & STEAM-TA \\
\hline Water solubility method & -1.31310111 \\
\hline Specified pressure [bar] & 1.31310111 \\
\hline Specified temperature [C] & 1.013529 \\
\hline Outlet temperature [C] & 500 \\
\hline Outlet pressure [bar] & 500 \\
\hline Calculated heat duty [Gcal/hr] & 1 \\
\hline Net heat duty [Gcal/hr] & 1 \\
\hline Vapor fraction & \\
\hline Number of fluid phases & \\
\hline Maximum number of pure solids & \\
\hline
\end{tabular}

Figure A5. Pyrolysis devol and pyrol results. 


\section{Appendix C}

\begin{tabular}{|c|c|c|c|c|c|c|c|c|c|c|}
\hline Description & & AIR & AIR-H & BOTTOMS & CHAR & DBIOMASS & EXHAUST & GASAIR & GASAIR-H & GASPROD \\
\hline From & & & HEATX-1 & 1-Sep & SSPLIT & DEVOL & 1-Sep & & HEATX-2 & GASIF \\
\hline To & & HEATX-1 & DRIER & PSPLIT & & MIX & & HEATX-2 & GASIF & SSPLIT \\
\hline Stream Class & & MCINCPSD & MCINCPSD & MCINCPSD & MCINCPSD & MCINCPSD & MCINCPSD & MCINCPSD & MCINCPSD & MCINCPSD \\
\hline Temperature & C & 25 & 50 & 25.751013 & & 200 & 25.751013 & 25 & 850 & 900 \\
\hline Pressure & bar & 1.013529 & 1.013529 & 1.013529 & & 1.013529 & 1.013529 & 1.013529 & 1.013529 & 1.013529 \\
\hline Mass Vapor Fraction & & 1 & 1 & 0 & & 0.595047813 & 1 & 1 & 1 & 1 \\
\hline Mass Liquid Fraction & & 0 & 0 & 0.054958908 & & 0.001202187 & 0 & 0 & 0 & 0 \\
\hline Mass Solid Fraction & & 0 & 0 & 0.945041092 & & 0.40375 & 0 & 0 & 0 & 0 \\
\hline Mass Enthalpy & kcal/kg & -0.067460867 & 5.984778022 & -1772.983632 & & -85.01319057 & -54.4993057 & -0.067314474 & 214.3379499 & -579.0881221 \\
\hline Mass Density & $\mathrm{kg} / \mathrm{cum}$ & 1.180215191 & 1.088654561 & 1259.742413 & & 0.567677961 & 1.165528866 & 1.176743131 & 0.312133676 & 0.18673497 \\
\hline Enthalpy Flow & $\mathrm{Gcal} / \mathrm{hr}$ & $-1.69 \mathrm{E}-05$ & 0.001496195 & -1.765303432 & & -0.079992938 & -0.013860904 & $-1.90 \mathrm{E}-05$ & 0.060504219 & -0.740047065 \\
\hline Mass Flows & $\mathrm{kg} / \mathrm{hr}$ & 250 & 250 & 995.6682061 & 0 & 940.9473684 & 254.3317566 & 282.2842105 & 282.2842105 & f 1277.952417 \\
\hline BIOMASS & $\mathrm{kg} / \mathrm{hr}$ & 0 & 0 & 940.9473684 & 0 & 0 & 0 & 0 & 0 & 0 \\
\hline $\mathrm{H} 2 \mathrm{O}$ & $\mathrm{kg} / \mathrm{hr}$ & 0 & 0 & 54.72077858 & 0 & 47.04736842 & 4.331815702 & 0 & 0 & 59.75103268 \\
\hline N2 & $\mathrm{kg} / \mathrm{hr}$ & 191.7707497 & 191.7707497 & 6.53E-06 & 0 & 7.86632 & 191.7707432 & 223.0045263 & 223.0045263 & 230.8523961 \\
\hline $\mathrm{O} 2$ & $\mathrm{~kg} / \mathrm{hr}$ & 58.22925031 & 58.22925031 & $5.26 \mathrm{E}-05$ & 0 & 452.76035 & 58.22919773 & 59.27968421 & 59.27968421 & $1.66 \mathrm{E}-15$ \\
\hline $\mathrm{NO} 2$ & $\mathrm{~kg} / \mathrm{hr}$ & 0 & 0 & 0 & 0 & 0 & 0 & 0 & 0 & $1.42 \mathrm{E}-20$ \\
\hline NO & $\mathrm{kg} / \mathrm{hr}$ & 0 & 0 & 0 & 0 & 0 & 0 & 0 & 0 & $2.67 \mathrm{E}-10$ \\
\hline s & $\mathrm{kg} / \mathrm{hr}$ & 0 & 0 & 0 & 0 & 1.69841 & 0 & 0 & 0 & $4.84 \mathrm{E}-08$ \\
\hline SO2 & $\mathrm{kg} / \mathrm{hr}$ & 0 & 0 & 0 & 0 & 0 & 0 & 0 & 0 & $4.38 \mathrm{E}-07$ \\
\hline $\mathrm{SO} 3$ & $\mathrm{~kg} / \mathrm{hr}$ & 0 & 0 & 0 & 0 & 0 & 0 & 0 & 0 & $1.48 \mathrm{E}-16$ \\
\hline $\mathrm{H} 2$ & $\mathrm{~kg} / \mathrm{hr}$ & 0 & 0 & 0 & 0 & 51.66742 & 0 & 0 & 0 & 56.15373149 \\
\hline CL2 & $\mathrm{kg} / \mathrm{hr}$ & 0 & 0 & 0 & 0 & 0 & 0 & 0 & 0 & 0 \\
\hline $\mathrm{HCL}$ & $\mathrm{kg} / \mathrm{hr}$ & 0 & 0 & 0 & 0 & 0 & 0 & 0 & 0 & 0 \\
\hline c & $\mathrm{kg} / \mathrm{hr}$ & 0 & 0 & 0 & 0 & 379.9075 & 0 & 0 & 0 & 0 \\
\hline $\mathrm{CO}$ & $\mathrm{kg} / \mathrm{hr}$ & 0 & 0 & 0 & 0 & 0 & 0 & 0 & 0 & 808.7174439 \\
\hline $\mathrm{CO} 2$ & $\mathrm{~kg} / \mathrm{hr}$ & 0 & 0 & 0 & 0 & 0 & 0 & 0 & 0 & 120.2340659 \\
\hline ASH & $\mathrm{kg} / \mathrm{hr}$ & 0 & 0 & 0 & 0 & 0 & 0 & 0 & 0 & 0 \\
\hline $\mathrm{CH} 4$ & $\mathrm{~kg} / \mathrm{hr}$ & 0 & 0 & 0 & 0 & 0 & 0 & 0 & 0 & 0.416115273 \\
\hline $\mathrm{C} 2 \mathrm{H} 4$ & $\mathrm{~kg} / \mathrm{hr}$ & 0 & 0 & 0 & 0 & 0 & 0 & 0 & 0 & 5.44E-06 \\
\hline $\mathrm{C} 2 \mathrm{H} 6$ & $\mathrm{~kg} / \mathrm{hr}$ & 0 & 0 & 0 & 0 & 0 & 0 & 0 & 0 & $4.88 \mathrm{E}-07$ \\
\hline С3H8 & $\mathrm{kg} / \mathrm{hr}$ & 0 & 0 & 0 & 0 & 0 & 0 & 0 & 0 & $1.50 \mathrm{E}-12$ \\
\hline $\mathrm{C} 3 \mathrm{H} 6$ & $\mathrm{~kg} / \mathrm{hr}$ & 0 & 0 & 0 & 0 & 0 & 0 & 0 & 0 & $1.06 \mathrm{E}-10$ \\
\hline N-BUT-01 & $\mathrm{kg} / \mathrm{hr}$ & 0 & 0 & 0 & 0 & 0 & 0 & 0 & 0 & 4.19E-18 \\
\hline N-DEC-01 & $\mathrm{kg} / \mathrm{hr}$ & 0 & 0 & 0 & 0 & 0 & 0 & 0 & 0 & 0 \\
\hline N-NON-01 & $\mathrm{kg} / \mathrm{hr}$ & 0 & 0 & 0 & 0 & 0 & 0 & 0 & 0 & 0 \\
\hline TOLUE-01 & $\mathrm{kg} / \mathrm{hr}$ & 0 & 0 & 0 & 0 & 0 & 0 & 0 & 0 & 2.40E-21 \\
\hline BENZE-01 & $\mathrm{kg} / \mathrm{hr}$ & 0 & 0 & 0 & 0 & 0 & 0 & 0 & 0 & $9.41 \mathrm{E}-17$ \\
\hline NAPHT-01 & $\mathrm{kg} / \mathrm{hr}$ & 0 & 0 & 0 & 0 & 0 & 0 & 0 & 0 & $1.49 \mathrm{E}-28$ \\
\hline PHENO-01 & $\mathrm{kg} / \mathrm{hr}$ & 0 & 0 & 0 & 0 & 0 & 0 & 0 & 0 & $1.52 \mathrm{E}-20$ \\
\hline METHA-01 & $\mathrm{kg} / \mathrm{hr}$ & 0 & 0 & 0 & 0 & 0 & 0 & 0 & 0 & $6.72 \mathrm{E}-07$ \\
\hline ETHAN-01 & $\mathrm{kg} / \mathrm{hr}$ & 0 & 0 & 0 & 0 & 0 & 0 & 0 & 0 & $8.32 \mathrm{E}-12$ \\
\hline 1-PRO-01 & $\mathrm{kg} / \mathrm{hr}$ & 0 & 0 & 0 & 0 & 0 & 0 & 0 & 0 & 1.97E-17 \\
\hline ACETA-01 & $\mathrm{kg} / \mathrm{hr}$ & 0 & 0 & 0 & 0 & 0 & 0 & 0 & 0 & $5.40 \mathrm{E}-08$ \\
\hline N-PRO-01 & $\mathrm{kg} / \mathrm{hr}$ & 0 & 0 & 0 & 0 & 0 & 0 & 0 & 0 & $1.15 \mathrm{E}-13$ \\
\hline N-BUT-02 & $\mathrm{kg} / \mathrm{hr}$ & 0 & 0 & 0 & 0 & 0 & 0 & 0 & 0 & 4.05E-23 \\
\hline N-BUT-03 & $\mathrm{kg} / \mathrm{hr}$ & 0 & 0 & 0 & 0 & 0 & 0 & 0 & 0 & $1.54 \mathrm{E}-19$ \\
\hline HYDRO-01 & $\mathrm{kg} / \mathrm{hr}$ & 0 & 0 & 0 & 0 & 0 & 0 & 0 & 0 & 1.805182957 \\
\hline AMMON-01 & $\mathrm{kg} / \mathrm{hr}$ & 0 & 0 & 0 & 0 & 0 & 0 & 0 & 0 & 0.022441274 \\
\hline
\end{tabular}

Figure A6. Gasification stream results (part 1). 


\begin{tabular}{|c|c|c|c|c|c|c|c|c|c|}
\hline Description & AIR & AIR-H & вOTTOMS & CHAR & DBIOMASS & EXHAUST & GASAIR & GASAIR-H & GASPROD \\
\hline \multicolumn{10}{|c|}{ Mass Fraction } \\
\hline BIOMASS & 0 & 0 & 0.945041092 & & 0 & 0 & 0 & 0 & 0 \\
\hline $\mathrm{H} 2 \mathrm{O}$ & 0 & 0 & 0.054958849 & & 0.05 & 0.017032146 & 0 & 0 & 0.046755288 \\
\hline N2 & 0.767082999 & 0.767082999 & 6.56E-09 & & 0.00836 & 0.754018081 & 0.79 & 0.79 & 0.180642403 \\
\hline $\mathrm{O} 2$ & 0.232917001 & 0.232917001 & $5.28 \mathrm{E}-08$ & & 0.481175 & 0.228949772 & 0.21 & 0.21 & 1.30E-18 \\
\hline NO2 & 0 & 0 & 0 & & 0 & 0 & 0 & 0 & $1.11 \mathrm{E}-23$ \\
\hline NO & 0 & 0 & 0 & & 0 & 0 & 0 & 0 & $2.09 \mathrm{E}-13$ \\
\hline$S$ & 0 & 0 & 0 & & 0.001805 & 0 & 0 & 0 & $3.79 \mathrm{E}-11$ \\
\hline $\mathrm{SO} 2$ & 0 & 0 & 0 & & 0 & 0 & 0 & 0 & $3.43 \mathrm{E}-10$ \\
\hline $\mathrm{SO} 3$ & 0 & 0 & 0 & & 0 & 0 & 0 & 0 & $1.16 \mathrm{E}-19$ \\
\hline $\mathrm{H} 2$ & 0 & 0 & 0 & & 0.05491 & 0 & 0 & 0 & 0.043940393 \\
\hline CL2 & 0 & 0 & 0 & & 0 & 0 & 0 & 0 & 0 \\
\hline $\mathrm{HCL}$ & 0 & 0 & 0 & & 0 & 0 & 0 & 0 & 0 \\
\hline c & 0 & 0 & 0 & & 0.40375 & 0 & 0 & 0 & 0 \\
\hline $\mathrm{CO}$ & 0 & 0 & 0 & & 0 & 0 & 0 & 0 & 0.632822814 \\
\hline $\mathrm{CO} 2$ & 0 & 0 & 0 & & 0 & 0 & 0 & 0 & 0.094083367 \\
\hline ASH & 0 & 0 & 0 & & 0 & 0 & 0 & 0 & 0 \\
\hline $\mathrm{CH} 4$ & 0 & 0 & 0 & & 0 & 0 & 0 & 0 & 0.000325611 \\
\hline $\mathrm{C} 2 \mathrm{H} 4$ & 0 & 0 & 0 & & 0 & 0 & 0 & 0 & $4.25 \mathrm{E}-09$ \\
\hline $\mathrm{C} 2 \mathrm{H} 6$ & 0 & 0 & 0 & & 0 & 0 & 0 & 0 & $3.82 \mathrm{E}-10$ \\
\hline $\mathrm{C} 3 \mathrm{H} 8$ & 0 & 0 & 0 & & 0 & 0 & 0 & 0 & $1.18 \mathrm{E}-15$ \\
\hline C3H6 & 0 & 0 & 0 & & 0 & 0 & 0 & 0 & $8.27 \mathrm{E}-14$ \\
\hline N-BUT-01 & 0 & 0 & 0 & & 0 & 0 & 0 & 0 & $3.28 \mathrm{E}-21$ \\
\hline N-DEC-01 & 0 & 0 & 0 & & 0 & 0 & 0 & 0 & 0 \\
\hline N-NON-01 & 0 & 0 & 0 & & 0 & 0 & 0 & 0 & 0 \\
\hline TOLUE-01 & 0 & 0 & 0 & & 0 & 0 & 0 & 0 & $1.88 \mathrm{E}-24$ \\
\hline BENZE-01 & 0 & 0 & 0 & & 0 & 0 & 0 & 0 & $7.36 \mathrm{E}-20$ \\
\hline NAPHT-01 & 0 & 0 & 0 & & 0 & 0 & 0 & 0 & $1.17 \mathrm{E}-31$ \\
\hline PHENO-01 & 0 & 0 & 0 & & 0 & 0 & 0 & 0 & $1.19 \mathrm{E}-23$ \\
\hline METHA-01 & 0 & 0 & 0 & & 0 & 0 & 0 & 0 & $5.26 \mathrm{E}-10$ \\
\hline ETHAN-01 & 0 & 0 & 0 & & 0 & 0 & 0 & 0 & $6.51 \mathrm{E}-15$ \\
\hline 1-PRO-01 & 0 & 0 & 0 & & 0 & 0 & 0 & 0 & $1.54 \mathrm{E}-20$ \\
\hline ACETA-01 & 0 & 0 & 0 & & 0 & 0 & 0 & 0 & $4.22 \mathrm{E}-11$ \\
\hline N-PRO-01 & 0 & 0 & 0 & & 0 & 0 & 0 & 0 & 8.97E-17 \\
\hline N-BUT-02 & 0 & 0 & 0 & & 0 & 0 & 0 & 0 & 3.17E-26 \\
\hline N-BUT-03 & 0 & 0 & 0 & & 0 & 0 & 0 & 0 & $1.21 \mathrm{E}-22$ \\
\hline HYDRO-01 & 0 & 0 & 0 & & 0 & 0 & 0 & 0 & 0.001412559 \\
\hline AMMON-01 & 0 & 0 & 0 & & 0 & 0 & 0 & 0 & $1.76 \mathrm{E}-05$ \\
\hline
\end{tabular}

Figure A7. Gasification stream results (part 1-mass fractions). 


\begin{tabular}{|c|c|c|c|c|c|c|c|c|c|}
\hline Description & & IN-DRY & IN-GAS & IN-VOLS & PURE-BM & PURE-H2O & VOLS-C & VOLS-H & WBIOMASS \\
\hline From & & DRIER & MIX & HEATX-1 & PSPLIT & PSPLIT & HEATX-2 & SSPLIT & \\
\hline To & & 1-Sep & GASIF & HEATX-2 & DEVOL & MIX & & HEATX-1 & DRIER \\
\hline Stream Class & & MCINCPSD & MCINCPSD & MCINCPSD & MCINCPSD & MCINCPSD & MCINCPSD & MCINCPSD & MCINCPSD \\
\hline Temperature & c & 25.751013 & 113.1250243 & 897.3856553 & 25.751013 & 25.751013 & 791.9561445 & 900 & 25 \\
\hline Pressure & bar & 1.013529 & 1.013529 & 1.013529 & 1.013529 & 1.013529 & 1.013529 & 1.013529 & 1.013529 \\
\hline Mass Vapor Fraction & & 0.203465411 & 0.616656396 & 1 & 0 & 0 & 1 & 1 & 0 \\
\hline Mass Liquid Fraction & & 0.043776671 & 0.001783263 & 0 & 0 & 1 & 0 & 0 & 0 \\
\hline Mass Solid Fraction & & 0.752757917 & 0.381560341 & 0 & 1 & 0 & 0 & 0 & 1 \\
\hline Mass Enthalpy & $\mathrm{kcal} / \mathrm{kg}$ & -1423.331512 & -289.9569047 & -580.272097 & -1654.285406 & -3814.048579 & -627.6316102 & 2 -579.0881221 & -1780.660584 \\
\hline Mass Density & $\mathrm{kg} / \mathrm{cum}$ & 5.707714552 & 0.687416759 & 0.187151948 & 1279.711701 & 993.232218 & 0.20567304 & $4 \quad 0.18673497$ & 1279.711701 \\
\hline Enthalpy Flow & Gcal/hr & -1.779164336 & -0.288700871 & -0.741560129 & -1.556595499 & -0.208707933 & -0.802083333 & 3 -0.740047065 & -1.780660584 \\
\hline Mass Flows & $\mathrm{kg} / \mathrm{hr}$ & 1249.999963 & 995.6682061 & 1277.952417 & 940.9473684 & 54.72083768 & 1277.952417 & 7 1277.952417 & 1000 \\
\hline BIOMASS & $\mathrm{kg} / \mathrm{hr}$ & 940.9473684 & 0 & 0 & 940.9473684 & 0 & 0 & 0 & 1000 \\
\hline $\mathrm{H} 2 \mathrm{O}$ & $\mathrm{kg} / \mathrm{hr}$ & 59.05259428 & 101.768147 & 59.75103268 & 0 & 54.72077858 & 59.75103268 & 59.75103268 & 0 \\
\hline N2 & $\mathrm{kg} / \mathrm{hr}$ & 191.7707497 & 7.866326531 & 230.8523961 & 0 & $6.53 \mathrm{E}-06$ & 230.8523961 & 230.8523961 & 0 \\
\hline $\mathrm{O} 2$ & $\mathrm{~kg} / \mathrm{hr}$ & 58.22925031 & 452.7604026 & $1.66 \mathrm{E}-15$ & 0 & 5.26E-05 & $1.66 \mathrm{E}-15$ & $1.66 \mathrm{E}-15$ & 0 \\
\hline NO2 & $\mathrm{kg} / \mathrm{hr}$ & 0 & 0 & $1.42 \mathrm{E}-20$ & 0 & 0 & $1.42 \mathrm{E}-20$ & $1.42 \mathrm{E}-20$ & 0 \\
\hline NO & $\mathrm{kg} / \mathrm{hr}$ & 0 & 0 & $2.67 \mathrm{E}-10$ & 0 & 0 & $2.67 \mathrm{E}-10$ & $2.67 \mathrm{E}-10$ & 0 \\
\hline $\mathrm{s}$ & $\mathrm{kg} / \mathrm{hr}$ & 0 & 1.69841 & 4.84E-08 & 0 & 0 & 4.84E-08 & 4.84E-08 & 0 \\
\hline $\mathrm{SO} 2$ & $\mathrm{~kg} / \mathrm{hr}$ & 0 & 0 & $4.38 \mathrm{E}-07$ & 0 & 0 & $4.38 \mathrm{E}-07$ & $4.38 \mathrm{E}-07$ & 0 \\
\hline $\mathrm{SO} 3$ & $\mathrm{~kg} / \mathrm{hr}$ & 0 & 0 & $1.48 \mathrm{E}-16$ & 0 & 0 & $1.48 \mathrm{E}-16$ & $1.48 \mathrm{E}-16$ & 0 \\
\hline $\mathrm{H} 2$ & $\mathrm{~kg} / \mathrm{hr}$ & 0 & 51.66742 & 56.15373149 & 0 & 0 & 56.15373149 & 56.15373149 & 0 \\
\hline $\mathrm{CL2}$ & $\mathrm{kg} / \mathrm{hr}$ & 0 & 0 & 0 & 0 & 0 & 0 & 0 & 0 \\
\hline $\mathrm{HCL}$ & $\mathrm{kg} / \mathrm{hr}$ & 0 & 0 & 0 & 0 & 0 & 0 & 0 & 0 \\
\hline C & $\mathrm{kg} / \mathrm{hr}$ & 0 & 379.9075 & 0 & 0 & 0 & 0 & 0 & 0 \\
\hline $\mathrm{CO}$ & $\mathrm{kg} / \mathrm{hr}$ & 0 & 0 & 808.7174439 & 0 & 0 & 808.7174439 & 808.7174439 & 0 \\
\hline $\mathrm{CO} 2$ & $\mathrm{~kg} / \mathrm{hr}$ & 0 & 0 & 120.2340659 & 0 & 0 & 120.2340659 & 120.2340659 & 0 \\
\hline ASH & $\mathrm{kg} / \mathrm{hr}$ & 0 & 0 & 0 & 0 & 0 & 0 & 0 & 0 \\
\hline $\mathrm{CH} 4$ & $\mathrm{~kg} / \mathrm{hr}$ & 0 & 0 & 0.416115273 & 0 & 0 & 0.416115273 & 0.416115273 & 0 \\
\hline $\mathrm{C} 2 \mathrm{H} 4$ & $\mathrm{~kg} / \mathrm{hr}$ & 0 & 0 & $5.44 \mathrm{E}-06$ & 0 & 0 & $5.44 \mathrm{E}-06$ & $5.44 \mathrm{E}-06$ & 0 \\
\hline $\mathrm{C} 2 \mathrm{H} 6$ & $\mathrm{~kg} / \mathrm{hr}$ & 0 & 0 & $4.88 \mathrm{E}-07$ & 0 & 0 & $4.88 \mathrm{E}-07$ & $4.88 \mathrm{E}-07$ & 0 \\
\hline $\mathrm{C} 3 \mathrm{H} 8$ & $\mathrm{~kg} / \mathrm{hr}$ & 0 & 0 & 1.50E-12 & 0 & 0 & $1.50 \mathrm{E}-12$ & 1.50E-12 & 0 \\
\hline $\mathrm{C} 3 \mathrm{H} 6$ & $\mathrm{~kg} / \mathrm{hr}$ & 0 & 0 & $1.06 \mathrm{E}-10$ & 0 & 0 & $1.06 \mathrm{E}-10$ & 1.06E-10 & 0 \\
\hline N-BUT-01 & $\mathrm{kg} / \mathrm{hr}$ & 0 & 0 & 4.19E- 18 & 0 & 0 & 4.19E-18 & 4.19E-18 & 0 \\
\hline N-DEC-01 & $\mathrm{kg} / \mathrm{hr}$ & 0 & 0 & 0 & 0 & 0 & 0 & 0 & 0 \\
\hline N-NON-01 & $\mathrm{kg} / \mathrm{hr}$ & 0 & 0 & 0 & 0 & 0 & 0 & 0 & 0 \\
\hline TOLUE-01 & $\mathrm{kg} / \mathrm{hr}$ & 0 & 0 & 2.40E-21 & 0 & 0 & $2.40 \mathrm{E}-21$ & 2.40E-21 & 0 \\
\hline BENZE-01 & $\mathrm{kg} / \mathrm{hr}$ & 0 & 0 & $9.41 \mathrm{E}-17$ & 0 & 0 & $9.41 \mathrm{E}-17$ & $9.41 \mathrm{E}-17$ & 0 \\
\hline NAPHT-01 & $\mathrm{kg} / \mathrm{hr}$ & 0 & 0 & $1.49 \mathrm{E}-28$ & 0 & 0 & $1.49 E-28$ & $1.49 \mathrm{E}-28$ & 0 \\
\hline PHENO-01 & $\mathrm{kg} / \mathrm{hr}$ & 0 & 0 & $1.52 \mathrm{E}-20$ & 0 & 0 & $1.52 \mathrm{E}-20$ & $1.52 \mathrm{E}-20$ & 0 \\
\hline METHA-01 & $\mathrm{kg} / \mathrm{hr}$ & 0 & 0 & $6.72 \mathrm{E}-07$ & 0 & 0 & $6.72 \mathrm{E}-07$ & $6.72 \mathrm{E}-07$ & 0 \\
\hline ETHAN-01 & $\mathrm{kg} / \mathrm{hr}$ & 0 & 0 & $8.32 \mathrm{E}-12$ & 0 & 0 & $8.32 \mathrm{E}-12$ & $8.32 \mathrm{E}-12$ & 0 \\
\hline 1-PRO-01 & $\mathrm{kg} / \mathrm{hr}$ & 0 & 0 & 1.97E-17 & 0 & 0 & 1.97E-17 & 1.97E-17 & 0 \\
\hline ACETA-01 & $\mathrm{kg} / \mathrm{hr}$ & 0 & 0 & 5.40E-08 & 0 & 0 & $5.40 \mathrm{E}-08$ & 5.40E-08 & 0 \\
\hline N-PRO-01 & $\mathrm{kg} / \mathrm{hr}$ & 0 & 0 & $1.15 \mathrm{E}-13$ & 0 & 0 & $1.15 \mathrm{E}-13$ & $1.15 \mathrm{E}-13$ & 0 \\
\hline N-BUT-02 & $\mathrm{kg} / \mathrm{hr}$ & 0 & 0 & $4.05 E-23$ & 0 & 0 & $4.05 E-23$ & 4.05E-23 & 0 \\
\hline N-BUT-03 & $\mathrm{kg} / \mathrm{hr}$ & 0 & 0 & $1.54 \mathrm{E}-19$ & 0 & 0 & $1.54 \mathrm{E}-19$ & $1.54 \mathrm{E}-19$ & 0 \\
\hline HYDRO-01 & $\mathrm{kg} / \mathrm{hr}$ & 0 & 0 & 1.805182957 & 0 & 0 & 1.805182957 & 1.805182957 & 0 \\
\hline AMMON-01 & $\mathrm{kg} / \mathrm{hr}$ & 0 & 0 & 0.022441274 & 0 & 0 & 0.022441274 & 0.022441274 & 0 \\
\hline
\end{tabular}

Figure A8. Gasification stream results (part 2). 


\begin{tabular}{|c|c|c|c|c|c|c|c|c|}
\hline \multicolumn{9}{|l|}{ Mass Fraction } \\
\hline BIOMASS & 0.752757917 & 0 & 0 & 1 & 0 & 0 & 0 & 1 \\
\hline $\mathrm{H} 2 \mathrm{O}$ & 0.047242077 & 0.102210904 & 0.046755288 & 0 & 0.99999892 & 0.046755288 & 0.046755288 & 0 \\
\hline N2 & 0.153416604 & 0.00790055 & 0.180642403 & 0 & 1.19E-07 & 0.180642403 & 0.180642403 & 0 \\
\hline $\mathrm{O} 2$ & 0.046583402 & 0.4547302 & 1.30E-18 & 0 & $9.61 \mathrm{E}-07$ & 1.30E-18 & 1.30E-18 & 0 \\
\hline NO2 & 0 & 0 & $1.11 \mathrm{E}-23$ & 0 & 0 & $1.11 \mathrm{E}-23$ & $1.11 \mathrm{E}-23$ & 0 \\
\hline NO & 0 & 0 & $2.09 \mathrm{E}-13$ & 0 & 0 & 2.09E-13 & $2.09 \mathrm{E}-13$ & 0 \\
\hline $\mathrm{S}$ & 0 & 0.001705799 & $3.79 \mathrm{E}-11$ & 0 & 0 & $3.79 \mathrm{E}-11$ & $3.79 \mathrm{E}-11$ & 0 \\
\hline $\mathrm{SO} 2$ & 0 & 0 & 3.43E-10 & 0 & 0 & 3.43E-10 & 3.43E-10 & 0 \\
\hline $\mathrm{SO} 3$ & 0 & 0 & $1.16 \mathrm{E}-19$ & 0 & 0 & $1.16 \mathrm{E}-19$ & $1.16 \mathrm{E}-19$ & 0 \\
\hline $\mathrm{H} 2$ & 0 & 0.051892206 & 0.043940393 & 0 & 0 & 0.043940393 & 0.043940393 & 0 \\
\hline CL2 & 0 & 0 & 0 & 0 & 0 & 0 & 0 & 0 \\
\hline $\mathrm{HCL}$ & 0 & 0 & 0 & 0 & 0 & 0 & 0 & 0 \\
\hline C & 0 & 0.381560341 & 0 & 0 & 0 & 0 & 0 & 0 \\
\hline $\mathrm{CO}$ & 0 & 0 & 0.632822814 & 0 & 0 & 0.632822814 & 0.632822814 & 0 \\
\hline $\mathrm{CO} 2$ & 0 & 0 & 0.094083367 & 0 & 0 & 0.094083367 & 0.094083367 & 0 \\
\hline ASH & 0 & 0 & 0 & 0 & 0 & 0 & 0 & 0 \\
\hline $\mathrm{CH} 4$ & 0 & 0 & 0.000325611 & 0 & 0 & 0.000325611 & 0.000325611 & 0 \\
\hline $\mathrm{C} 2 \mathrm{H} 4$ & 0 & 0 & $4.25 \mathrm{E}-09$ & 0 & 0 & 4.25E-09 & $4.25 \mathrm{E}-09$ & 0 \\
\hline $\mathrm{C} 2 \mathrm{H} 6$ & 0 & 0 & $3.82 \mathrm{E}-10$ & 0 & 0 & $3.82 \mathrm{E}-10$ & $3.82 \mathrm{E}-10$ & 0 \\
\hline $\mathrm{C} 3 \mathrm{H} 8$ & 0 & 0 & $1.18 \mathrm{E}-15$ & 0 & 0 & $1.18 \mathrm{E}-15$ & $1.18 \mathrm{E}-15$ & 0 \\
\hline $\mathrm{C} 3 \mathrm{H} 6$ & 0 & 0 & $8.27 E-14$ & 0 & 0 & $8.27 E-14$ & $8.27 \mathrm{E}-14$ & 0 \\
\hline N-BUT-01 & 0 & 0 & $3.28 \mathrm{E}-21$ & 0 & 0 & $3.28 \mathrm{E}-21$ & $3.28 \mathrm{E}-21$ & 0 \\
\hline N-DEC-01 & 0 & 0 & 0 & 0 & 0 & 0 & 0 & 0 \\
\hline $\mathrm{N}-\mathrm{NON}-01$ & 0 & 0 & 0 & 0 & 0 & 0 & 0 & 0 \\
\hline TOLUE-01 & 0 & 0 & $1.88 \mathrm{E}-24$ & 0 & 0 & $1.88 \mathrm{E}-24$ & $1.88 \mathrm{E}-24$ & 0 \\
\hline BENZE-01 & 0 & 0 & $7.36 \mathrm{E}-20$ & 0 & 0 & $7.36 \mathrm{E}-20$ & $7.36 \mathrm{E}-20$ & 0 \\
\hline NAPHT-01 & 0 & 0 & $1.17 E-31$ & 0 & 0 & $1.17 E-31$ & $1.17 E-31$ & 0 \\
\hline PHENO-01 & 0 & 0 & $1.19 E-23$ & 0 & 0 & $1.19 \mathrm{E}-23$ & $1.19 \mathrm{E}-23$ & 0 \\
\hline METHA-01 & 0 & 0 & $5.26 \mathrm{E}-10$ & 0 & 0 & $5.26 \mathrm{E}-10$ & $5.26 \mathrm{E}-10$ & 0 \\
\hline ETHAN-01 & 0 & 0 & $6.51 \mathrm{E}-15$ & 0 & 0 & $6.51 \mathrm{E}-15$ & $6.51 \mathrm{E}-15$ & 0 \\
\hline 1-PRO-01 & 0 & 0 & $1.54 \mathrm{E}-20$ & 0 & 0 & $1.54 \mathrm{E}-20$ & $1.54 \mathrm{E}-20$ & 0 \\
\hline ACETA-01 & 0 & 0 & $4.22 \mathrm{E}-11$ & 0 & 0 & $4.22 \mathrm{E}-11$ & 4. $22 \mathrm{E}-11$ & 0 \\
\hline N-PRO-01 & 0 & 0 & 8.97E-17 & 0 & 0 & 8.97E-17 & 8.97E-17 & 0 \\
\hline N-BUT-02 & 0 & 0 & $3.17 E-26$ & 0 & 0 & $3.17 E-26$ & $3.17 E-26$ & 0 \\
\hline N-BUT-03 & 0 & 0 & $1.21 \mathrm{E}-22$ & 0 & 0 & $1.21 \mathrm{E}-22$ & $1.21 \mathrm{E}-22$ & 0 \\
\hline HYDRO-01 & 0 & 0 & 0.001412559 & 0 & 0 & 0.001412559 & 0.001412559 & 0 \\
\hline AMMON-01 & 0 & 0 & $1.76 \mathrm{E}-05$ & 0 & 0 & $1.76 \mathrm{E}-05$ & $1.76 \mathrm{E}-05$ & 0 \\
\hline
\end{tabular}

Figure A9. Gasification stream results (part 2-mass fractions). 


\begin{tabular}{|c|c|c|}
\hline Name & HEATX-1 & HEATX-2 \\
\hline Hot side property method & PENG-ROB & PENG-ROB \\
\hline Hot side use true species approach for electrolytes & YES & YES \\
\hline Hot side free-water phase properties method & STEAM-TA & STEAM-TA \\
\hline Hot side water solubility method & \multicolumn{2}{|c|}{3} \\
\hline Cold side property method & PENG-ROB & PENG-ROB \\
\hline Cold side use true species approach for electrolytes & YES & YES \\
\hline Cold side free-water phase properties method & STEAM-TA & STEAM-TA \\
\hline Cold side water solubility method & \multicolumn{2}{|l|}{3} \\
\hline Exchanger specification & \multicolumn{2}{|l|}{50} \\
\hline Units of exchanger specification & C & C \\
\hline Minimum temperature approach $[\mathrm{C}]$ & \multicolumn{2}{|l|}{1} \\
\hline Inlet hot stream temperature [C] & 900 & 897.385655 \\
\hline Inlet hot stream pressure [bar] & 1.013529 & 1.013529 \\
\hline Inlet hot stream vapor fraction & \multicolumn{2}{|l|}{1} \\
\hline Outlet hot stream temperature [C] & 897.385655 & 5791.956144 \\
\hline Outlet hot stream pressure [bar] & 1.013529 & 1.013529 \\
\hline Outlet hot stream vapor fraction & \multicolumn{2}{|l|}{1} \\
\hline Inlet cold stream temperature [C] & \multicolumn{2}{|l|}{25} \\
\hline Inlet cold stream pressure [bar] & 1.013529 & 1.013529 \\
\hline Inlet cold stream vapor fraction & \multicolumn{2}{|l|}{1} \\
\hline Outlet cold stream temperature $[\mathrm{C}]$ & \multicolumn{2}{|r|}{850} \\
\hline Outlet cold stream pressure [bar] & 1.013529 & 1.013529 \\
\hline Outlet cold stream vapor fraction & \multicolumn{2}{|l|}{1} \\
\hline Heat duty [Gcal/hr] & 0.00151306 & 0.060523201 \\
\hline Calculated heat duty [Gcal/hr] & 0.00151306 & 0.060523201 \\
\hline Required exchanger area [sqm] & 0.002404036 & 0.320402393 \\
\hline Actual exchanger area [sqm] & 0.002404036 & 0.320402393 \\
\hline Average U (Dirty) [kcal/hr-sqm-K] & 730.868444 & $4 \quad 730.868444$ \\
\hline \multicolumn{3}{|l|}{ Average U (Clean) } \\
\hline UA [cal/sec-K] & 0.488064953 & 65.0477773 \\
\hline LMTD (Corrected) [C] & 861.144331 & 258.456183 \\
\hline LMTD correction factor & 1 & \\
\hline
\end{tabular}

Figure A10. Gasification heat exchanger results. 


\begin{tabular}{l|r|}
\hline Name & \multicolumn{1}{l|}{ DRIER } \\
\hline Property method & PENG-ROB \\
\hline Use true species approach for electrolytes & YES \\
\hline Free-water phase properties method & STEAM-TA \\
\hline Water solubility method & 3 \\
\hline Specified pressure [bar] & 1.013529 \\
\hline Specified heat duty [Gcal/hr] & 0 \\
\hline Outlet temperature [C] & 25.751013 \\
\hline Outlet pressure [bar] & 1.013529 \\
\hline Calculated heat duty [Gcal/hr] & 0 \\
\hline Net heat duty [Gcal/hr] & 0 \\
\hline Calculated vapor fraction & 0.745676291 \\
\hline & \\
\hline & \\
\hline Name & $1-S e p$ \\
\hline Property method & PENG-ROB \\
\hline Use true species approach for electrolytes & YES \\
\hline Free-water phase properties method & STEAM-TA \\
\hline Water solubility method & 3 \\
\hline Pressure [bar] & 1.013529 \\
\hline Specified heat duty [Gcal/hr] & 0 \\
\hline Outlet temperature [C] & 25.751013 \\
\hline Outlet pressure [bar] & 1.013529 \\
\hline Vapor fraction & 0.745676291 \\
\hline Heat duty [Gcal/hr] & 0 \\
\hline Net duty [Gcal/hr] & 0 \\
\hline
\end{tabular}

Figure A11. Gasification drier and separator results. 


\begin{tabular}{|l|r|}
\hline Name & DEVOL \\
\hline Property method & PENG-ROB \\
\hline Use true species approach for electrolytes & YES \\
\hline Free-water phase properties method & STEAM-TA \\
\hline Water solubility method & 3 \\
\hline Specified pressure [bar] & 1.013529 \\
\hline Specified temperature [C] & 200 \\
\hline Outlet temperature [C] & 200 \\
\hline Outlet pressure [bar] & 1.013529 \\
\hline Calculated heat duty [Gcal/hr] & 1.47660256 \\
\hline Net heat duty [Gcal/hr] & 1.47660256 \\
\hline Calculated vapor fraction & 0.999172994 \\
\hline & \\
\hline & GASIF \\
\hline Name & PENG-ROB \\
\hline Property method & YES \\
\hline Use true species approach for electrolytes & STEAM-TA \\
\hline Free-water phase properties method & STE \\
\hline Water solubility method & 1.013529 \\
\hline Specified pressure [bar] & 900 \\
\hline Specified temperature [C] & 900 \\
\hline Outlet temperature [C] & 1.013529 \\
\hline Outlet pressure [bar] & -0.51185041 \\
\hline Calculated heat duty [Gcal/hr] & -0.51185041 \\
\hline Net heat duty [Gcal/hr] & 1 \\
\hline Vapor fraction & 1 \\
\hline Number of fluid phases & 1 \\
\hline Maximum number of pure solids & \\
\hline
\end{tabular}

Figure A12. Gasification devol and gasif results.

\section{Appendix D}

\begin{tabular}{|c|c|c|c|c|c|}
\hline Name & PUMP-1 & PUMP-2 & PUMP-3 & PUMP-4 & PUMP-5 \\
\hline Property method & NRTL & NRTL & NRTL & NRTL & NRTL \\
\hline Henry's component list ID & $\mathrm{HC}$ & $\mathrm{HC}$ & $\mathrm{HC}$ & $\mathrm{HC}$ & $\mathrm{HC}$ \\
\hline Use true species approach for electrolytes & YES & YES & YES & YES & YES \\
\hline Free-water phase properties method & STEAM-TA & STEAM-TA & STEAM-TA & STEAM-TA & STEAM-TA \\
\hline Water solubility method & 3 & 3 & 3 & 3 & 3 \\
\hline Specified discharge pressure [bar] & 8.61845 & 1.01325 & 1.01325 & 1.01325 & 2.4318 \\
\hline Electricity [Watt] & 3390.75424 & -438.550352 & 0 & 0 & 665.353153 \\
\hline Volumetric flow rate [cum/sec] & 0.001390603 & 0.001681306 & 0.00152386 & 0.001523527 & 0.001543549 \\
\hline Calculated discharge pressure [bar] & 8.61845 & 1.01325 & 1.01325 & 1.01325 & 2.4318 \\
\hline Calculated pressure change [bar] & 7.6052 & -7.6052 & 0 & 0 & 1.41855 \\
\hline \multicolumn{6}{|l|}{ Calculated pressure ratio } \\
\hline NPSH available [J/kg] & 99.107896 & 281.783715 & 83.1955769 & 83.1955769 & 0 \\
\hline \multicolumn{6}{|l|}{ NPSH required } \\
\hline Head developed [J/kg] & 761.458722 & -856.7348 & 0 & 0 & 145.529793 \\
\hline Pump efficiency used & 0.311901566 & 0.342974593 & 0.326988169 & 0.326952321 & 0.329088529 \\
\hline Net work required [Watt] & 3390.75424 & -438.550352 & 0 & 0 & 665.353153 \\
\hline
\end{tabular}

Figure A13. Fermentation pump results. 


\begin{tabular}{|l|l|l|l|l|}
\hline Name & HEATEX-1 & HEATEX-2 & HEATEX-3 & HEATEX-4 \\
\hline Property method & NRTL & NRTL & NRTL & NRTL \\
\hline Henry's component list ID & HC & HC & HC & HC \\
\hline Use true species approach for electrolytes & YES & YES & YES & YES \\
\hline Free-water phase properties method & STEAM-TA & STEAM-TA & STEAM-TA & \multicolumn{2}{l|}{ STEAM-TA } \\
\hline Water solubility method & 3 & 3 & 3 & 3 \\
\hline Specified pressure [bar] & 8.61845 & 1.01325 & 1.01325 & 2.4318 \\
\hline Specified temperature [C] & 160 & 50 & 30 & 30 \\
\hline Calculated pressure [bar] & 8.61845 & 1.01325 & 1.01325 & 2.4318 \\
\hline Calculated temperature [C] & 160 & 50 & 30 & 30 \\
\hline Calculated vapor fraction & 0 & 0 & 0 & 0 \\
\hline Calculated heat duty [Watt] & 888364.178 & -743620.581 & -128664.658 & -665.2468 \\
\hline Net duty [Watt] & 888364.178 & -743620.581 & -128664.658 & -665.2468 \\
\hline
\end{tabular}

Figure A14. Fermentation heat exchanger results.

\begin{tabular}{|l|l|l|l|}
\hline Name & FERMENT & HYDROLYS & \multicolumn{2}{l|}{ PRETREAT } \\
\hline Property method & NRTL & NRTL & \multicolumn{1}{l|}{ NRTL } \\
\hline Henry's component list ID & HC & HC & \multicolumn{1}{l|}{ HC } \\
\hline Use true species approach for electrolytes & YES & YES & \multicolumn{2}{|l}{ YES } \\
\hline Free-water phase properties method & STEAM-TA & STEAM-TA & STEAM-TA \\
\hline Water solubility method & 3 & 3 & 3 \\
\hline Specified pressure [bar] & 1.01325 & 1.01325 & 8.61845 \\
\hline Specified temperature [C] & 30 & 50 & 160 \\
\hline Outlet temperature [C] & 30 & 50 & 160 \\
\hline Outlet pressure [bar] & 1.01325 & 1.01325 & 8.61845 \\
\hline Net heat duty [Watt] & -76952.8835 & -3807.31559 & 24966.9917 \\
\hline Calculated vapor fraction & 0.036917291 & 0 & 0 \\
\hline
\end{tabular}

Figure A15. Fermentation ferment, hydrolys, pretreat reactor results. 


\begin{tabular}{|c|c|}
\hline Name & DISTILLA \\
\hline Property method & NRTL \\
\hline Henry's component list ID & $\mathrm{HC}$ \\
\hline Use true species approach for electrolytes & YES \\
\hline Free-water phase properties method & STEAM-TA \\
\hline Water solubility method & 3 \\
\hline Number of stages & 45 \\
\hline Condenser & PARTIAL-V \\
\hline Reboiler & KETTLE \\
\hline Number of phases & 2 \\
\hline Free-water & NO \\
\hline Specified reflux ratio & 6 \\
\hline Calculated molar reflux ratio & 6 \\
\hline Calculated bottoms rate $[\mathrm{kmol} / \mathrm{sec}]$ & 0.027355696 \\
\hline Calculated boilup rate [kmol/sec] & 0.372771749 \\
\hline Calculated distillate rate $[\mathrm{kmol} / \mathrm{sec}]$ & 0.051027467 \\
\hline Condenser / top stage temperature [C] & 98.5483619 \\
\hline Condenser / top stage pressure [bar] & 1.01325 \\
\hline Condenser / top stage heat duty [Watt] & -12484772.3 \\
\hline Condenser / top stage reflux rate $[\mathrm{kmol} / \mathrm{sec}]$ & 0.306164799 \\
\hline Reboiler pressure [bar] & 1.41855 \\
\hline Reboiler temperature [C] & 109.817316 \\
\hline Reboiler heat duty [Watt] & 15000025.1 \\
\hline Calculated molar boilup ratio & 13.6268419 \\
\hline Calculated mass boilup ratio & 13.296096 \\
\hline
\end{tabular}

Figure A16. Fermentation distillation column results.

\begin{tabular}{|c|c|c|c|c|c|c|c|c|c|c|}
\hline Description & & BOTTOMS & CO2OUT & DISTFEED & ETHANOL & FERMFEED & HYDFEED & LIGNIN & PREFEED & s1 \\
\hline From & & DISTILLA & FERMVENT & HEATEX-4 & DISTILLA & HEATEX-3 & HEATEX-2 & CENTFRIG & HEATEX-1 & \\
\hline To & & & & DISTILLA & & FERMENT & HYDROLYS & & PRETREAT & PUMP-1 \\
\hline Stream Class & & MIXCISLD & MIXCISLD & MIXCISLD & MIXCISLD & MIXCISLD & MIXCISLD & MIXCISLD & MIXCISLD & MIXCISLD \\
\hline Temperature & c & 109.8173157 & 30 & 30 & 98.54836191 & 30 & 50 & 50 & 160 & 20 \\
\hline Pressure & bar & 1.41855 & 1.01325 & 2.4318 & 1.01325 & 1.01325 & 1.01325 & 1.01325 & 8.61845 & 1.01325 \\
\hline Molar Vapor Fraction & & 0 & 1 & 0 & 1 & 0 & 0 & 0 & 0 & 0 \\
\hline Molar Liquid Fraction & & 1 & 0 & 1 & 0 & 1 & 0.988684517 & 0.656640111 & 0.980649107 & 0.980649107 \\
\hline Molar Solid Fraction & & 0 & 0 & 0 & 0 & 0 & 0.011315483 & 0.343359889 & 0.019350893 & 0.019350893 \\
\hline Mass Vapor Fraction & & 0 & 1 & 0 & 1 & 0 & 0 & 0 & 0 & 0 \\
\hline Mass Liquid Fraction & & 1 & 0 & 1 & 0 & 1 & 0.912527174 & 0.2 & 0.849184783 & 0.849184783 \\
\hline Mass Solid Fraction & & 0 & 0 & 0 & 0 & 0 & 0.087472826 & 0.8 & 0.150815217 & 0.150815217 \\
\hline Molar Enthalpy & $\mathrm{J} / \mathrm{kmol}$ & -281800751.6 & -383820093.6 & -286002987 & -238963707 & -304808697.9 & -299770778.7 & -533904329.7 & -288187576.3 & -299530700 \\
\hline Mass Enthalpy & $\mathrm{J} / \mathrm{kg}$ & -15262653.84 & -8926293.957 & -14899795.2 & -12199902.47 & -14380321.58 & -14291991.51 & -7671976.657 & -13852329.2 & -14397559.8 \\
\hline Molar Entropy & $\mathrm{J} / \mathrm{kmol}-\mathrm{K}$ & -146043.6161 & -963.3970378 & -168014.9023 & -44584.61474 & -180452.9023 & -199772.1175 & -1238075.784 & -193795.1353 & -224589.0991 \\
\hline Mass Entropy & $\mathrm{J} / \mathrm{kg}-\mathrm{K}$ & -7909.890747 & -22.40519791 & -8753.012201 & -2276.194818 & -8513.44067 & -9524.415356 & - -17790.61901 & -9315.162181 & -10795.33745 \\
\hline Molar Density & $\mathrm{kmol} / \mathrm{cum}$ & 49.89377709 & 0.04020053 & 50.78114255 & 0.032786776 & 51.65436075 & 52.1096129 & 44.93369939 & 47.01755389 & 54.91114619 \\
\hline Mass Density & $\mathrm{kg} / \mathrm{cum}$ & 921.2096422 & 1.728575305 & 974.7488644 & 0.642205906 & 1094.878049 & 1092.985482 & 3127.003343 & 978.1658162 & 1142.38623 \\
\hline Enthalpy Flow & Watt & -7708855.789 & -1153232.104 & -22417818.72 & -12193712.57 & -23494098.04 & -23375346.12 & -13720.05159 & -22656253.98 & -23548008.91 \\
\hline Average MW & & 18.4634176 & 42.99881848 & 19.19509518 & 19.58734568 & 21.19623655 & 20.97473808 & 69.59149559 & 20.80426852 & 20.80426852 \\
\hline Mole Flows & $\mathrm{kmol} / \mathrm{sec}$ & 0.027355696 & 0.003004616 & 0.078383163 & 0.051027467 & 0.077078175 & 0.077977401 & 2.57E-05 & 0.078616345 & 0.078616345 \\
\hline \multicolumn{11}{|l|}{ Mole Fractions } \\
\hline Mass Flows & $\mathrm{kg} / \mathrm{hr}$ & 1818.286723 & 465.1018211 & 5416.460179 & 3598.173455 & 5881.562 & 5888 & 6.438 & 5888 & 5888 \\
\hline $\mathrm{H} 2 \mathrm{O}$ & $\mathrm{kg} / \mathrm{hr}$ & 1769.250406 & 7.904589249 & 4892.931065 & 3123.680659 & 4900.835654 & 4958.561247 & 1.07289798 & 5000 & 5000 \\
\hline ETHANOL & $\mathrm{kg} / \mathrm{hr}$ & $2.70 E-16$ & 10.52036693 & 465.9740593 & 465.9740593 & 0 & 0 & 0 & 0 & 0 \\
\hline GLUCOSE & $\mathrm{kg} / \mathrm{hr}$ & 49.03631728 & $3.22 \mathrm{E}-13$ & 49.03631728 & $9.78 \mathrm{E}-219$ & 980.7263456 & 414.3987528 & 0.21470202 & 0 & 0 \\
\hline $\mathrm{CO} 2$ & $\mathrm{~kg} / \mathrm{hr}$ & $8.94 \mathrm{E}-63$ & 446.676865 & 8.518737133 & 8.518737133 & 0 & 0 & 0 & 0 & 0 \\
\hline CELLULOS & $\mathrm{kg} / \mathrm{hr}$ & 0 & 0 & 0 & 0 & 0 & 515.04 & 5.1504 & 888 & 888 \\
\hline \multicolumn{11}{|l|}{ Mass Fractions } \\
\hline $\mathrm{H} 2 \mathrm{O}$ & & 0.973031582 & 0.016995395 & 0.903344787 & 0.868129538 & 0.833254101 & 0.842146951 & 0.16665082 & 0.849184783 & 0.849184783 \\
\hline ETHANOL & & $1.48 \mathrm{E}-19$ & 0.022619492 & 0.08602926 & 0.129502945 & 0 & 0 & 0 & 0 & 0 \\
\hline GLUCOSE & & 0.026968418 & $6.93 \mathrm{E}-16$ & 0.009053204 & $2.72 E-222$ & 0.166745899 & 0.070380223 & 0.03334918 & 0 & 0 \\
\hline $\mathrm{CO} 2$ & & $4.92 \mathrm{E}-66$ & 0.960385113 & 0.00157275 & 0.002367517 & 0 & 0 & 0 & 0 & 0 \\
\hline
\end{tabular}

Figure A17. Fermentation stream results (part 1). 


\begin{tabular}{|c|c|c|c|c|c|c|c|c|c|c|c|}
\hline Description & & S2 & s3 & S4 & S5 & s6 & S7 & 58 & S9 & S10 & S11 \\
\hline From & & PUMP-1 & PRETREAT & PUMP-2 & HYDROLYS & PUMP-3 & CENTFRIG & PUMP-4 & FERMENT & FERMVENT & FERMVENT \\
\hline To & & HEATEX-1 & PUMP-2 & HEATEX-2 & PUMP-3 & CENTFRIG & PUMP-4 & HEATEX-3 & FERMVENT & PUMP-5 & PUMP-5 \\
\hline Stream Class & & MIXCISLD & MIXCISLD & MIXCISLD & MIXCISLD & MIXCISLD & MIXCISLD & MIXCISLD & MIXCISLD & MIXCISLD & MIXCISLD \\
\hline Temperature & C & 20.58781063 & 160 & 159.942003 & 50 & 50 & 50 & 50 & 30 & 30 & 30 \\
\hline Pressure & bar & 8.61845 & 8.61845 & 1.01325 & 1.01325 & 1.01325 & 1.01325 & 1.01325 & 1.01325 & 1.01325 & 1.01325 \\
\hline Molar Vapor Fraction & & 0 & 0 & 0 & 0 & 0 & 0 & 0 & 0.03691729 & 0 & 0 \\
\hline Molar Liquid Fraction & & 0.980649107 & 0.988684517 & 0.988684517 & 0.999885563 & 0.999885563 & 1 & 1 & 0.96308271 & 1 & 1 \\
\hline Molar Solid Fraction & & 0.019350893 & 0.011315483 & 0.011315483 & 0.000114437 & 0.000114437 & 0 & 0 & 0 & 0 & 0 \\
\hline Mass Vapor Fraction & & 0 & 0 & 0 & 0 & 0 & 0 & 0 & 0.079077942 & 0 & 0 \\
\hline Mass Liquid Fraction & & 0.849184783 & 0.912527174 & 0.912527174 & 0.999125272 & 0.999125272 & 1 & 1 & 0.920922058 & 1 & 1 \\
\hline Mass Solid Fraction & & 0.150815217 & 0.087472826 & 0.087472826 & 0.000874728 & 0.000874728 & 0 & 0 & 0 & 0 & 0 \\
\hline Molar Enthalpy & $\mathrm{J} / \mathrm{kmol}$ & -299487569.6 & -290228794.4 & -290234418.5 & -303216333.6 & -303216333.6 & -303139423 & -303139423 & -289614130.8 & -286002988.3 & -286002988.3 \\
\hline Mass Enthalpy & $\mathrm{J} / \mathrm{kg}$ & -14395486.65 & -13837064.06 & -13837332.19 & -14294319.36 & -14294319.36 & -14301568.22 & -14301568.22 & -14427423.08 & -14899795.27 & -14899795.27 \\
\hline Molar Entropy & $\mathrm{J} / \mathrm{kmol}-\mathrm{K}$ & -224442.8219 & -174967.7172 & -174980.0447 & -175379.0835 & -175379.0835 & -175024.7842 & -175024.7842 & -161847.8176 & -168014.9067 & -168014.9067 \\
\hline Mass Entropy & $\mathrm{J} / \mathrm{kg}-\mathrm{K}$ & -10788.30634 & -8341.830849 & -8342.418579 & -8267.775677 & -8267.775677 & -8257.351904 & -8257.351904 & -8062.613978 & -8753.012434 & -8753.012434 \\
\hline Molar Density & $\mathrm{kmol} / \mathrm{cum}$ & 54.88101857 & 45.73070571 & 45.73439726 & 50.58981894 & 50.58981894 & 50.59194213 & 50.59194213 & 1.06690132 & 50.78114255 & 50.78114255 \\
\hline Mass Density & $\mathrm{kg} /$ cum & 1141.759447 & 959.1895746 & 959.2670039 & 1073.129754 & 1073.129754 & 1072.358773 & $\begin{array}{ll}3 & 1072.358773\end{array}$ & 21.41683216 & 974.7488644 & 974.7488644 \\
\hline Enthalpy Flow & Watt & -23544618.16 & -22631286.99 & -22631725.54 & -23379153.44 & -23379153.44 & -23365433.38 & - -23365433.38 & -23571050.93 & -22417818.82 & -22417818.82 \\
\hline Average MW & & 20.80426852 & 20.97473808 & 20.97473808 & 21.21236598 & 21.21236598 & 21.19623655 & 21.19623655 & 20.07386414 & 19.19509518 & $\begin{array}{l}3 \quad 19.19509518 \\
\end{array}$ \\
\hline Mole Flows & $\mathrm{kmol} / \mathrm{sec}$ & 0.078616345 & 0.077977401 & 0.077977401 & 0.077103872 & 0.077103872 & 0.077078175 & 0.077078175 & 0.081387779 & 0.078383163 & 0.078383163 \\
\hline \multicolumn{12}{|c|}{ ( } \\
\hline Mass Flows & & 88 & 5888 & 5888 & 5888 & 5888 & 5881.562 & 5881.562 & 5881.562 & 5416.460179 & 5416.460179 \\
\hline $\mathrm{H} 2 \mathrm{O}$ & & 5000 & 4958.561247 & 4958.561247 & 4901.908552 & 4901.908552 & 4900.835654 & 4900.83 & 4900.835654 & 4892.931065 & 4892.931065 \\
\hline ETHANOL & $\mathrm{kg} / \mathrm{hr}$ & 0 & 0 & 0 & 0 & 0 & 0 & 0 & 476.4944263 & 465.9740593 & 465.9740593 \\
\hline GLUCOSE & & 0 & 414.3987528 & 414.3987528 & 980.9410477 & 980.9410477 & 980.7263456 & 980.7263456 & 49.03631728 & 49.03631728 & 49.03631728 \\
\hline $\mathrm{CO} 2$ & $\mathrm{~g} / \mathrm{hr}$ & 0 & 0 & 0 & 0 & 0 & 0 & 0 & 455.1956021 & 8.518737133 & 8.518737133 \\
\hline CELLULOS & $\mathrm{kg} / \mathrm{hr}$ & 888 & 515.04 & 515.04 & 5.1504 & 5.1504 & 0 & 0 & 0 & 0 & 0 \\
\hline \multicolumn{12}{|l|}{ Mass Fractions } \\
\hline $\mathrm{H} 2 \mathrm{O}$ & & 0.849184783 & 0.842146951 & 0.842146951 & 0.83252523 & 0.83252523 & 0.833254101 & 1 0.833254101 & 0.833254101 & 0.903344787 & 0.903344787 \\
\hline ETHANOL & & 0 & 0 & 0 & 0 & 0 & 0 & 0 & 0.081014946 & 0.08602926 & 0.08602926 \\
\hline GLUCOSE & & 0 & 0.070380223 & 0.070380223 & 0.166600042 & 0.166600042 & 0.166745899 & 0.166745899 & 0.008337295 & 0.009053204 & 0.009053204 \\
\hline $\mathrm{CO} 2$ & & 0 & 0 & 0 & 0 & 0 & 0 & 0 & 0.077393659 & 0.00157275 & 0.00157275 \\
\hline CELLULOS & & 0.150815217 & 0.087472826 & 0.087472826 & 0.000874728 & 0.000874728 & 0 & 0 & 0 & 0 & 0 \\
\hline
\end{tabular}

Figure A18. Fermentation stream results (part 2).

\section{References}

1. Tawalbeh, M.; Al-Ismaily, M.; Kruczek, B.; Tezel, F.H. Modeling the transport of $\mathrm{CO}_{2}, \mathrm{~N}_{2}$, and their binary mixtures through highly permeable silicalite-1 membranes using Maxwell-Stefan equations. Chemosphere 2021, 263, 127935. [CrossRef] [PubMed]

2. Alami, A.H.; Hawili, A.A.; Tawalbeh, M.; Hasan, R.; al Mahmoud, L.; Chibib, S.; Mahmood, A.; Aokal, K.; Rattanapanya, P. Materials and logistics for carbon dioxide capture, storage and utilization. Sci. Total Environ. 2020, 717, 137221. [CrossRef] [PubMed]

3. Kazim, A.; Veziroglu, T.N. Utilization of solar-hydrogen energy in the UAE to maintain its share in the world energy market for the 21st century. Renew. Energy 2001, 24, 259-274. [CrossRef]

4. Al-Othman, A.; Darwish, N.N.; Qasim, M.; Tawalbeh, M.; Darwish, N.A.; Hilal, N. Nuclear desalination: A state-of-the-art review. Desalination 2019, 457, 39-61. [CrossRef]

5. Demirbaş, A. Mechanisms of liquefaction and pyrolysis reactions of biomass. Energy Convers. Manag. 2001, 24, 259-274. [CrossRef]

6. Almomani, F.; Al Ketife, A.; Judd, S.; Shurair, M.; Bhosale, R.R.; Znad, H.; Tawalbeh, M. Impact of $\mathrm{CO}_{2}$ concentration and ambient conditions on microalgal growth and nutrient removal from wastewater by a photobioreactor. Sci. Total Environ. 2019, 662, 662-671. [CrossRef]

7. Lee, J.; Yu, S.; Park, J.; Jo, H.; Park, J.; Ryu, C.; Jeong, Y.-G. Reduction of Unburned Carbon Release and NOx Emission from a Pulverized Wood Pellet Boiler Retrofitted for Fuel Switching from Coal. Energies 2020, 13, 5077. [CrossRef]

8. Jain, N.; Bhatia, A.; Pathak, H. Emission of Air Pollutants from Crop Residue Burning in India. Aerosol Air Qual. Res. 2014, 14, 422-430. [CrossRef]

9. Sharma, A.R.; Kharol, S.K.; Badarinath, K.V.S.; Singh, D. Impact of agriculture crop residue burning on atmospheric aerosol loading-A study over Punjab State, India. Ann. Geophys. 2010, 28, 367-379. [CrossRef]

10. Fedenko, J.R.; Erickson, J.; Woodard, K.; Sollenberger, L.; Vendramini, J.; Gilbert, R.; Helsel, Z.; Peter, G. Biomass production and composition of perennial grasses grown for bioenergy in a subtropical climate across Florida, USA. Bioenergy Res. 2013, 6, 1082-1093. [CrossRef]

11. Cardona, C.A.; Rincón, L.E.; Jaramillo, J.J. Integral analysis of feedstocks and technologies for biodiesel production in tropical and subtropical countries. In Proceedings of the World Renewable Energy Congress-Sweden, Linköping, Sweden, 8-13 May 2011; pp. 216-223.

12. Almomani, F.; Baranova, E.A. Electro-oxidation of two reactive azo dyes on boron-doped diamond electrode. Water Sci. Technol. 2012, 66, 465-471. [CrossRef] [PubMed] 
13. Huang, J.J. Life cycle analysis of hybrid poplar trees for cellulosic ethanol. Bachelor's Thesis, Massachusetts Institute of Technology, Cambridge, MA, USA, 2007.

14. Hill, J. Environmental costs and benefits of transportation biofuel production from food-and lignocellulose-based energy crops: A review. In Sustainable Agriculture; Springer: Dordrecht, The Netherlands, 2009; pp. 125-139.

15. Gurram, R.; Al-Shannag, M.; Knapp, S.; Das, T.; Singsaas, E.; Alkasrawi, M. Technical possibilities of bioethanol production from coffee pulp: A renewable feedstock. Clean Technol. Environ. Policy 2016, 18, 269-278. [CrossRef]

16. Bani-Melhem, K.; Al-Qodah, Z.; Al-Shannag, M.; Qasaimeh, A.; Qtaishat, M.R.; Alkasrawi, M. On the performance of real grey water treatment using a submerged membrane bioreactor system. J. Memb. Sci. 2015, 476, 40-49. [CrossRef]

17. Al-Qodah, Z.; Al-Shannag, M.; Amro, A.; Bob, M.; Bani-Melhem, K.; Alkasrawi, M. Impact of surface modification of green algal biomass by phosphorylation on the removal of copper (II) ions from water. Turk. J. Chem. 2017, 41, 190-208. [CrossRef]

18. Pacheco, R.; Silva, C. Global Warming Potential of Biomass-to-Ethanol: Review and Sensitivity Analysis through a Case Study. Energies 2019, 12, 2535. [CrossRef]

19. Naik, S.N.; Goud, V.V.; Rout, P.K.; Dalai, A.K. Production of first and second generation biofuels: A comprehensive review. Renew. Sustain. Energy Rev. 2010, 14, 578-597. [CrossRef]

20. Al-Bsoul, A.; Al-Shannag, M.; Tawalbeh, M.; Al-Taani, A.A.; Lafi, W.K.; Al-Othman, A.; Alsheyab, M. Optimal conditions for olive mill wastewater treatment using ultrasound and advanced oxidation processes. Sci. Total Environ. 2020, 700, 134576. [CrossRef]

21. Salameh, T.; Tawalbeh, M.; Al-Shannag, M.; Saidan, M.; Melhem, K.B.; Alkasrawi, M. Energy saving in the process of bioethanol production from renewable paper mill sludge. Energy 2020, 196, 117085. [CrossRef]

22. Jambo, S.A.; Abdulla, R.; Mohd Azhar, S.H.; Marbawi, H.; Gansau, J.A.; Ravindra, P. A review on third generation bioethanol feedstock. Renew. Sustain. Energy Rev. 2016, 65, 756-769. [CrossRef]

23. Tawalbeh, M.; Al-Othman, A.; Singh, K.; Douba, I.; Kabakebji, D.; Alkasrawi, M. Microbial desalination cells for water purification and power generation: A critical review. Energy 2020, 209, 118493. [CrossRef]

24. Alkasrawi, M.; Rajangam, A.S.; Tawalbeh, M.; Kafiah, F.; Al-Othman, A.; Al-Asheh, S.; Sun, Q. Techno-economic analysis and a novel assessment technique of paper mill sludge conversion to bioethanol toward sustainable energy production. Int. J. Energy Res. 2020, 5667. [CrossRef]

25. Tawalbeh, M.; Rajangam, A.S.; Salameh, T.; Al-Othman, A.; Alkasrawi, M. Characterization of paper mill sludge as a renewable feedstock for sustainable hydrogen and biofuels production. Int J. Hydrog. Energy 2020, in press. [CrossRef]

26. Bensidhom, G.; Ben Hassen-Trabelsi, A.; Alper, K.; Sghairoun, M.; Zaafouri, K.; Trabelsi, I. Pyrolysis of Date palm waste in a fixed-bed reactor: Characterization of pyrolytic products. Bioresour. Technol. 2018, 247, 363-369. [CrossRef]

27. Weiss, E.; Zohary, D.; Hopf, M. Current State of the Art. In Domestication of Plants in the Old World-The Origin and Spread of Domesticated Plants in South-west Asia, Europe, and the Mediterranean Basin, 3rd ed.; Oxford University Press: Oxford, UK, 2011; pp. 1-8.

28. Tengberg, M. Beginnings and early history of date palm garden cultivation in the Middle East. J. Arid Environ. 2012, 86, 139-147. [CrossRef]

29. Chao, C.T.; Krueger, R.R. The Date Palm (Phoenix dactylifera L.): Overview of Biology, Uses, and Cultivation. HortScience 2007, 42, 1077-1082. [CrossRef]

30. Manickavasagan, A.; Essa, M.M.; Sukumar, E. Dates: Production, Processing, Food, and Medicinal Values; CRC Press: Boca Raton, FL, USA, 2012.

31. Food and Agriculture Organization of the United Nations. Crop Statistics; FAO: Rome Italy, 2018.

32. Food and Agriculture Organization of the United Nations. FAO Renews Support to Date Palm Production; FAO: Rome, Italy, 2018.

33. Al-Sadi, A.M.; Al-Wehaibi, A.N.; Al-Shariqi, R.M.; Al-Hammadi, M.S.; Al-Hosni, I.A.; Al-Mahmooli, I.H.; Al-Ghaithi, A.G. "Population genetic analysis reveals diversity in Lasiodiplodia species infecting date palm, Citrus, and mango in Oman and the UAE. Plant Dis. 2013, 1363-1369. [CrossRef] [PubMed]

34. Al-Khayri, J.M.; Naik, P.M.; Jain, S.M.; Johnson, D.V. Advances in Date Palm (Phoenix dactylifera L.) Breeding. In Advances in Plant Breeding Strategies: Fruits; Springer International Publishing: Cham, Switzerland, 2018; pp. 727-771. 
35. Al-Muaini, A.; Green, S.; Dakheel, A.; Abdullah, A.-H.; Abdelwahid, W.; Dixon, S.; Kemp, P.; Clothier, B. Irrigation management with saline groundwater of a date palm cultivar in the hyper-arid United Arab Emirates. Agric. Water Manag. 2019, 211, 123-131. [CrossRef]

36. El Hadrami, A.; Al-Khayri, J.M. Socioeconomic and Traditional Importance of Date Palm. Emir. J. Food Agric. 2013, 25, 371-385.

37. Fatima, G.; Khan, I.A.; Buerkert, A. Socio-economic characterisation of date palm (Phoenix dactylifera L.) growers and date value chains in Pakistan. Springerplus 2016, 5, 1222. [CrossRef]

38. Ibrahim, S.A.; Ayad, A.A.; Williams, L.L.; Ayivi, R.D.; Gyawali, R.; Krastanov, A.; Aljaloud, S.O. Date fruit: A review of the chemical and nutritional compounds, functional effects and food application in nutrition bars for athletes. Int. J. Food Sci. Technol. 2020, 14783. [CrossRef]

39. Alkasrawi, M. Development of Simultaneous Saccharification and Fermentation for Production of Ethanol from Softwood. Ph.D. Thesis, Lund University, Lund, Sweden, 2004.

40. Liu, C.-G.; Xiao, Y.; Xia, X.X.; Zhao, X.Q.; Peng, L.; Srinophakun, P.; Bai, F.W. Cellulosic ethanol production: Progress, challenges and strategies for solutions. Biotechnol. Adv. 2019, 37, 491-504. [CrossRef] [PubMed]

41. Tahir, A.H.F.; Al-Obaidy, A.H.M.J.; Mohammad, F.H. Biochar from date palm waste, production, characteristics and use in the treatment of pollutants: A Review. In Proceedings of the 4th International Conference on Buildings, Construction and Environmental Engineering, Istanbul, Turkey, 7-9 October 2019; IOP Publishing Ltd.: Bristol, UK, 2020.

42. Ranzi, E.; Cuoci, A.; Faravelli, T.; Frassoldati, A.; Migliavacca, G.; Pierucci, S.; Sommariva, S. Chemical Kinetics of Biomass Pyrolysis. Energy Fuels 2008, 22, 4292-4300. [CrossRef]

43. McKendry, P. Energy production from biomass (part 1): Overview of biomass. Bioresour. Technol. 2002, 83, 37-46. [CrossRef]

44. Makkawi, Y.; Yu, X.; Ocone, R. Parametric analysis of biomass fast pyrolysis in a downer fluidized bed reactor. Renew. Energy 2019, 143, 1225-1234. [CrossRef]

45. Makkawi, Y.; El Sayed, Y.; Salih, M.; Nancarrow, P.; Banks, S.; Bridgwater, T. Fast pyrolysis of date palm (Phoenix dactylifera) waste in a bubbling fluidized bed reactor. Renew. Energy 2019, 143, 719-730. [CrossRef]

46. El May, Y.; Jeguirim, M.; Dorge, S.; Trouvé, G.; Said, R. Study on the thermal behavior of different date palm residues: Characterization and devolatilization kinetics under inert and oxidative atmospheres. Energy 2012, 44, 702-709. [CrossRef]

47. Yu, X.; Blanco, P.H.; Makkawi, Y.; Bridgwater, A.V. CFD and experimental studies on a circulating fluidised bed reactor for biomass gasification. Chem. Eng. Process. Process. Intensif. 2018, 130, 284-295. [CrossRef]

48. Al Afif, R.; Wendland, M.; Amon, T.; Pfeifer, C. Supercritical carbon dioxide enhanced pre-treatment of cotton stalks for methane production. Energy 2020, 194, 116903. [CrossRef]

49. Chen, X.; Lin, Q.; Rizwan, M.; Zhao, X.; Li, G. Steam explosion of crop straws improves the characteristics of biochar as a soil amendment. J. Integr. Agric. 2019, 18, 1486-1495. [CrossRef]

50. Steinbach, D.; Wüst, D.; Zielonka, S.; Krümpel, J.; Munder, S.; Pagel, M.; Kruse, A. Steam Explosion Conditions Highly Influence the Biogas Yield of Rice Straw. Molecules 2019, 24, 3492. [CrossRef]

51. Millati, R.; Wikandari, R.; Ariyanto, T.; Putri, R.U.; Taherzadeh, M.J. Pretreatment technologies for anaerobic digestion of lignocelluloses and toxic feedstocks. Bioresour. Technol. 2020, 304, 122998. [CrossRef]

52. Schneider, W.D.H.; Fontana, R.C.; Baudel, H.M.; de Siqueira, F.G.; Rencoret, J.; Gutiérrez, A.; de Eugenio, L.I.; Prieto, A.; Martínez, M.J.; Martínez, Á.T.; et al. Degradation and detoxification of eucalyptus wastes by on-site manufacturing fungal enzymes to enhance second-generation ethanol yield. Appl. Energy 2020, 262, 114493. [CrossRef]

53. Ghorbannezhad, P.; Kool, F.; Rudi, H.; Ceylan, S. Sustainable production of value-added products from fast pyrolysis of palm shell residue in tandem micro-reactor and pilot plant. Renew. Energy 2020, 145, 663-670. [CrossRef]

54. Samiran, N.A.; Jaafar, M.N.M.; Ng, J.-H.; Lam, S.S.; Chong, C.T. Progress in biomass gasification technique-With focus on Malaysian palm biomass for syngas production. Renew. Sustain. Energy Rev. 2016, 62, 1047-1062. [CrossRef]

55. Khan, Z.; Yusup, S.; Ahmad, M.M.; Rashidi, N.A. Integrated catalytic adsorption (ICA) steam gasification system for enhanced hydrogen production using palm kernel shell. Int. J. Hydrogen Energy 2014, 39, 3286-3293. [CrossRef]

56. Lahijani, P.; Zainal, Z.A. Gasification of palm empty fruit bunch in a bubbling fluidized bed: A performance and agglomeration study. Bioresour. Technol. 2011, 102, 2068-2076. [CrossRef] [PubMed] 
57. Atnaw, S.M.; Sulaiman, S.A.; Yusup, S. Syngas production from downdraft gasification of oil palm fronds. Energy 2013, 61, 491-501. [CrossRef]

58. Shemfe, M.B.; Fidalgo, B.; Gu, S. Heat integration for bio-oil hydroprocessing coupled with aqueous phase steam reforming. Chem. Eng. Res. Des. 2016, 107, 73-80. [CrossRef]

59. Tong, K.; Gleeson, M.J.; Rong, G.; You, F. Optimal design of advanced drop-in hydrocarbon biofuel supply chain integrating with existing petroleum refineries under uncertainty. Biomass BioEnergy 2014, 60, 108-120. [CrossRef]

60. Marbe, Å.; Harvey, S. Opportunities for integration of biofuel gasifiers in natural-gas combined heat-and-power plants in district-heating systems. Appl. Energy 2006, 83, 723-748. [CrossRef]

61. Salman, C.A.; Naqvi, M.; Thorin, E.; Yan, J. Impact of retrofitting existing combined heat and power plant with polygeneration of biomethane: A comparative techno-economic analysis of integrating different gasifiers. Energy Convers. Manag. 2017, 152, 250-265. [CrossRef]

62. Andersson, V.; Heyne, S.; Harvey, S.; Berntsson, T. Integration of algae-based biofuel production with an oil refinery: Energy and carbon footprint assessment. Int. J. Energy Res. 2020, 44, 10860-10877. [CrossRef]

63. van Dyk, S.; Su, J.; Mcmillan, J.D.; Saddler, J. Potential synergies of drop-in biofuel production with further co-processing at oil refineries. Biofuels Bioprod. Biorefin. 2019, 13, 760-775. [CrossRef]

64. U.S. Department of Energy. Clean Cities Alternative Fuel Price Report; Allegheny Science and Technology: Bridgeport, WV, USA, 2020. Available online: https://afdc.energy.gov/files/u/publication/alternative_fuel_ price_report_july_2020.pdf (accessed on 20 September 2020).

65. Mathis, W.; Thornhill, J. Hydrogen's Plunging Price Boosts Role as Climate Solution, Bloomberg. Available online: https://www.eea.europa.eu/themes/industry/industrial-pollution-in-europe/benefits-of-anambitious-implementation (accessed on 10 October 2020).

66. García-Velásquez, C.A.; Cardona, C.A. Comparison of the biochemical and thermochemical routes for bioenergy production: A techno-economic (TEA), energetic and environmental assessment. Energy 2019, 172, 232-242. [CrossRef]

67. Gonsalez, R.; Treasure, T.; Phillips, R.; Jameel, H.; Saloni, D. Economics of cellulosic ethanol production: Green liquor pretreatment for softwood and hardwood, greenfield and repurpose scenarios. BioResources 2011, 6, 2551-2567. [CrossRef]

68. Olba-Zięty, E.; Gołaszewski, J.; Krzykowski, M.; Zięty, J.; van Klink, H. Economic and legal aspects of the direct processing of sugar beet to ethanol. IOP Conf. Ser. Earth Environ. Sci. 2019, 214, 012050. [CrossRef]

69. Rocha-Meneses, L.; Raud, M.; Orupõld, K.; Kikas, T. Potential of bioethanol production waste for methane recovery. Energy 2019, 173, 133-139. [CrossRef]

70. Ghofrani-Isfahani, P.; Baniamerian, H.; Tsapekos, P.; Alvarado-Morales, M.; Kasama, T.; Shahrokhi, M.; Vossoughi, M.; Angelidaki, I. Effect of metal oxide based $\mathrm{TiO}_{2}$ nanoparticles on anaerobic digestion process of lignocellulosic substrate. Energy 2020, 191, 116580. [CrossRef]

71. Pangsang, N.; Rattanapan, U.; Thanapimmetha, A.; Srinopphakhun, P.; Liu, C.G.; Zhao, X.Q.; Bai, F.W.; Sakdaronnarong, C. Chemical-free fractionation of palm empty fruit bunch and palm fiber by hot-compressed water technique for ethanol production. Energy Rep. 2019, 5, 337-348. [CrossRef]

72. Demirbas, A. The social, economic, and environmental importance of biofuels in the future. Energy Sources Part B Econ. Plan. Policy 2017, 12, 47-55. [CrossRef]

73. Demirbas, A. Political, economic and environmental impacts of biofuels: A review. Appl. Energy 2009, 86, S108-S117. [CrossRef]

74. Schneider, D.R.; Ragossnig, A.M. Biofuels from waste. Waste Manag. Res. 2013, 31, 339-340. [CrossRef] [PubMed]

75. Beckman, J.; Hertel, T.; Taheripour, F.; Tyner, W. Structural change in the biofuels era. Eur. Rev. Agric. Econ. 2012, 39, 137-156. [CrossRef]

Publisher's Note: MDPI stays neutral with regard to jurisdictional claims in published maps and institutional affiliations. 